\title{
Control transfers in corporate Germany: Their frequency, causes, and consequences
}

\author{
JENS KÖKE* \\ Centre for European Economic Research \\ Mannheim, Germany
}

August 2001

\begin{abstract}
This study examines changes in block ownership for a large sample of listed and non-listed German firms. The frequency of block trading is similar to other countries, and the vast majority of block trades leads to changes in ultimate ownership (control transfers). Such changes are more likely for firms with high leverage, while they are less likely for larger firms and firms with high ownership concentration. Only for listed firms poor performance is related to more frequent control transfers. Control transfers are followed by increased management turnover, and for listed firms also by asset divestitures and employee layoffs.
\end{abstract}

Keywords: Corporate governance, ownership structure, management turnover, restructuring

JEL classification: G32, G34, J63

* Address: Jens Köke, Centre for European Economic Research, Department of International Finance and Financial Management, P.O. Box 1034 43, 68034 Mannheim, Germany; phone: $++49 / 621 / 1235-190$, fax: $++49 / 621 / 1235-223$, email: koeke@zew.de

Acknowledgements: Financial support from the German Science Foundation (DFG) is gratefully acknowledged (grant no. BO 934, 71). Comments from Axel Börsch-Supan, Silke Januszewski, Mattias Nilsson, Joachim Winter, seminar participants at the University of Mannheim and the ZEW, and participants of the Financial Management Association meeting in Paris are highly appreciated. Matthias Braun, Gregor Führich, and Heiko Truppel provided excellent research assistance. Special thanks to Dirk-Christian Guennemann for invaluable feedback and editing. 


\section{Introduction}

The market for corporate control is an important element of corporate governance (e.g., Shleifer and Vishny, 1997). Particularly active markets have been described for the US (e.g., Jensen and Ruback, 1983; Jarrell et al., 1988) and the UK (Franks and Mayer, 1990). To a large extent these markets are based on hostile takeovers. Focusing solely on hostile takeovers, there is no market for corporate control in the bank-based economies of Continental Europe (OECD, 1998), in particular not in Germany (Franks and Mayer, 1998). For Germany, this lack is typically attributed to bank voting power, complex ownership structures, and political resistance. This study shows that control transfers in Germany occur more frequently than often assumed, and that there are some indications characterizing these control transfers as disciplinary.

Since hostile takeovers are rare, we use a broader concept to examine takeover activity, namely the market for large share blocks. While this approach does not distinguish between hostile and friendly takeovers, it does account for partial firm sales. The apparent drawback of analyzing both forms of takeovers in combination is insignificant in light of Schwert (2000). He shows for the US that hostile and friendly takeovers are not distinguishable in economic terms, but negotiations are publicized earlier in hostile transactions. Our approach - tracking block ownership through time to identify changes in corporate control - is supported by Jenkinson and Ljungqvist (2001) who apply a similar methodology to assemble case-study evidence on (hostile) stake building in Germany.

The following analysis addresses two main questions. First, we investigate how frequently corporate ownership changes. This involves tracking the names of all large investors in almost 1,000 listed and non-listed German companies through the years 1987-1994. We find that trading activity of large blocks is similar to other countries, and that the vast majority of block trades leads to changes in ultimate ownership (control transfers). Second, we examine both the causes and consequences of control transfers. They are more likely for firms with high leverage, while they are less likely for larger firms and firms with high ownership concentration. In addition, high insider ownership and complex ownership structures make control transfers less likely for listed and non-listed firms, respectively. Changes in ownership are also more likely when performance is very poor, but only for listed firms. Control transfers are followed by increased management turnover, and for listed firms also by asset divestitures and employee layoffs. We do not find evidence that changes in control are related to significant improvements in performance.

Related work exists for the US. Bethel et al. (1998) investigate the antecedents and effects of block purchases executed by activist shareholders. Their results suggest that these partial firm purchases play an important role in limiting agency costs. Denis and Sarin (1999) find that a substantial fraction of US firms exhibits large changes in ownership and board structure, and show, based on case study evidence, that these changes are typically followed by large-scale asset reallocations. Denis and Kruse (2000) analyze the consequences of disciplinary events such as takeovers and find a substantial amount of corporate restructuring and improvements in operating performance.

This study extends the literature in several ways. First, it provides large-sample evidence on causes as well as consequences of control transfers, and hence complements the work of Denis and Sarin (1999) and Denis and Kruse (2000). In contrast to Bethel et al. (1998) we focus on purchases of blocks that are likely to change corporate control, and thus make our analysis less vulnerable to potentially misspecified shareholder types. Second, previous 
studies focus on the market-based economy of the US, while this study examines a bankbased economy. The German economy is particularly interesting for analyzing changes in ownership because ownership structures are highly complex and therefore perceived to be stable. One reason for this assumption is the wide-spread use of such forms of organization as pyramids, cross ownership, and large conglomerates (e.g., La Porta et al., 1999). Third, since the majority of companies in Continental Europe and particularly in Germany is not listed on a stock exchange, this study covers listed as well as non-listed firms. Previous studies examining control transfers focus exclusively on listed firms, and so far nothing is known about control transfers in non-listed firms. Fourth, due to the complexity of ownership structures in Germany, analyzing direct share ownership is not sufficient. We therefore examine ultimate ownership of firms. As this approach requires data on individual shareholders, our analysis also accounts for changes within shareholder categories, and in this sense extends the work of Denis and Sarin (1999) that is based on changes between shareholder categories. This is essential because positive and negative gross changes in a category might offset each other, causing them to be neglected.

The study proceeds as follows: Section 2 briefly reviews the evidence on the market for large share blocks and draws on the relevant theoretical and empirical literature to formulate a set of hypotheses. Section 3 describes the data used for this study and defines the concept of control that is applied to identify the ultimate owner. Section 4 describes the frequency of control transfers in Germany as well as the type of buyers and sellers of control blocks. Section 5 analyzes the causes and consequences of control transfers and tests the hypotheses put forward in Section 2. Section 6 concludes.

\section{Literature and hypotheses}

Evidence on the market for large share blocks is accumulating. For Belgium, Renneboog (2000) reports 127 cases in which blocks larger than ten percent are purchased during the years 1989-1994. For a sample of over 1,000 firm years, this implies that on average $12.4 \%$ of Belgian firms experienced such a block purchase in any year. For the UK, the corresponding annual rate is 9.0\% (Franks et al., 1999). For the US, Bethel et al. (1998) find 244 purchases of blocks larger than five percent during the years 1980-1989. For a sample of almost 3,700 firm years, this translates into an annual rate of $6.6 \%$. For Germany, so far no comparable figure on block trading is available. Franks and Mayer (1994) compare the ownership structures of 171 listed German companies for the years 1988 and 1991. They find that in about a fifth of firms a new major shareholder is in place by 1991. Although their analysis is conducted on the basis of direct ownership and changes in ultimate ownership are neglected, their results suggest that there is a market for large share blocks in Germany. Similarly, recent case-study evidence collected by Jenkinson and Ljungqvist (2001) indicates that control changes in Germany are more frequent than previously assumed. While their study focuses on hostile control transactions and neglects cases without perceived hostility, their methodology - tracking block ownership through time - appears to be crucial to identifying changes in control.

We now turn to the literature on causes and consequences of ownership changes to formulate two sets of hypotheses. The first set focuses on the causes and distinguishes between firm-specific and owner-specific characteristics as well as performance. 
Hypothesis 1 Changes in ultimate ownership are less likely for firms with high concentration of ownership.

Hypothesis 2 Changes in ultimate ownership are more likely for firms with high leverage.

Hypothesis 3 Changes in ultimate ownership are less likely for firms with complex ownership structures.

Hypothesis 4 Changes in ultimate ownership are less likely for large firms.

Hypothesis 5 Changes in ultimate ownership are less likely for firms with high insider ownership.

Hypothesis 6 Changes in ultimate ownership are more likely for firms with poor performance.

The first hypothesis (H1) follows Holmström and Tirole (1993) who argue that takeovers require low concentration of ownership and, in turn, high market liquidity because only then are capital markets able to determine the necessity of a takeover. The few cases of hostile takeovers in Germany support Holmström and Tirole because in all cases the shares of the takeover target were widely dispersed. Note that Grossman and Hart (1980) argue to the opposite that some share concentration is required for takeovers to be effective because under dispersed ownership shareholders would prefer to free-ride.

The second hypothesis (H2) is derived from Mitchell and Mulherin (1996) who argue that changes in the firm's growth opportunities, leverage, or firm size could make adjustments in ownership necessary, for example as a result of economic shocks to an industry. Consistent with this view, Zingales (1998) reports that following deregulation in the US trucking industry firms faced increasing leverage, and that this has lead to a higher probability of market exit. We expect leverage to have a similar impact on changes in ownership.

The third and fourth hypothesis consider firm-specific characteristics that might deter changes in ownership. The third hypothesis (H3) focuses on defensive mechanisms implemented against a change in ownership. In the US, defensive mechanisms encompass employee stock ownership plans, anti-takeover charter amendments, and poison pills, as noted by Bethel et al. (1998). In Germany, pyramids (Franks and Mayer, 1995) and crossholding of shares (Wenger and Kaserer, 1998) are likely to hinder ownership changes. The fourth hypothesis (H4) establishes that also the size of a firm can deter changes in ownership. Shleifer and Vishny (1992) argue that the market for corporate control is less liquid as firm size increases. Bethel et al. (1998) and Mulherin and Boone (2000) provide empirical evidence that smaller firms are more likely to become takeover targets.

The fifth hypothesis (H5) emphasizes owner-specific characteristics, in particular the fraction of shares owned by insiders. Jensen and Meckling (1976) argue that incentives of managers and owners are better aligned when managers hold a large fraction of shares. In this case outside investors should have little opportunity to improve on performance. However, managers might also become entrenched when owning large blocks (Fama and Jensen, 1983). Irrespective whether insider ownership is good or bad for shareholders, we 
expect high insider ownership to reduce the likelihood of a control change. This conjecture is in line with evidence on the US (Barber et al., 1995) and Canada (St-Pierre et al., 1996).

Finally, the sixth hypothesis $(\mathbf{H 6})$ focuses on performance. When managers diverge from the interest of shareholders and performance suffers, both the market for corporate control as well as internal control mechanisms could act as disciplining devices (e.g., Jensen, 1988; Shleifer and Vishny, 1997). Denis and Sarin (1999) and Maksimovic and Phillips (2001) provide empirical evidence for the US. Hence, irrespective of the causes of bad performance, we expect that poor performance makes block purchases more likely.

The second set of hypotheses concerns the consequences of ownership changes. We focus on three aspects: governance changes, corporate restructuring, and performance.

Hypothesis 7 Changes in ultimate ownership are followed by increased management turnover.

Hypothesis $\mathbf{8}$ Changes in ultimate ownership are followed by increased asset divestitures, employee layoffs, and cost cutting.

Hypothesis 9 Changes in ultimate ownership are followed by improvements in performance.

The seventh hypothesis $(\mathbf{H} 7)$ follows from considerations that takeovers can be disciplinary, and that different management teams compete with each other (Jensen and Ruback, 1983). The empirical evidence suggests that changes in board and ownership structure are strongly related to top executive turnover and prior performance (e.g., Denis and Sarin, 1999, and Kole and Lehn, 1999, for the US; Renneboog, 2000, for Belgium). For Germany, Jenkinson and Ljungqvist (2001) report that following hostile control changes typically incumbent management is removed or resigns.

The eighth hypothesis (H8) is concerned with three different aspects of corporate restructuring as a consequence of a change in ownership: asset divestitures, employee layoffs, and cost cutting. Previous empirical studies find that following changes in ownership asset divestitures increase, the frequency of mergers and acquisitions decreases, and share repurchases increase (e.g., Bethel et al., 1998, and Denis and Sarin, 1999, for the US; Franks and Mayer, 1995, for the UK).

Finally, the ninth hypothesis (H9) establishes that changes in ownership ultimately affect performance. Bethel et al. (1998) show that industry-adjusted operating profitability rises in firms that experience activist block purchases, whereas it falls in firms that do not experience a block purchase. Denis and Kruse (2000) find for a sample of firms that experienced a large performance decline that industry-adjusted operating performance improves significantly in combination with major asset restructuring.

\section{$3 \quad$ Data and measurement issues}

The sample used in this analysis is based on firm-level data for the years 1987-1994. It comprises firms with headquarters located in Germany. Companies from former Eastern 
Germany are included only after 1990. Contrary to previous empirical studies on corporate governance in Germany (e.g., Cable, 1985; Becht and Böhmer, 2000; Gorton and Schmid, 2000) we do not restrict our analysis to large listed firms; we also examine non-listed and medium-sized firms, part of which are subsidiaries of conglomerates. This is significant because focusing only on listed firms could cause a selection bias (Börsch-Supan and Köke, 2000). Also, in contrast to previous studies the sample encompasses firms from a broader range of industries, including manufacturing, construction, and trade.

\subsection{Sample selection}

The analysis of the market for corporate control as a governance device places several major requirements on the data set used. First, the firms in the sample need to face the classical agency problem (Jensen and Meckling, 1976). This is the case when the manager of a firm does not own one hundred percent of the shares. Otherwise, no separation of ownership and control would exist and agency costs would be zero by definition. To meet this requirement we select only medium-sized and large German corporations because we expect agency problems to be most severe there.

Second, to assess the performance of firms we collect balance sheet data and capital market data. This is necessary because theory provides little guidance on which performance measure to use. Third, ownership data are a crucial element of the data set. As shown by Wenger and Kaserer (1998), Böhmer (2000), and Köke (2001), ownership structures of large German firms are complex. Firms are often owned by pyramids of shareholders or cross shareholdings. To account for these conditions, the analysis of direct ownership (Gorton and Schmid, 2000) must be extended to the analysis of ultimate ownership (see Section 3.3). Fourth, any consequences of changes in ownership are likely to be most visible through governance changes and various corporate restructuring activities. Therefore, data on board structure, asset divestitures, employment, and labor costs are included.

In total, the analysis of the frequency of control transfers (Section 4) is based on data from 946 firms (4,882 firm years) for the years 1987-1994. This sample (in the following, Sample I) includes firms with at least two continuous years of data because changes in ownership must be calculated. The analysis of causes and consequences of control transfers (Section 5) is based on a subsample and encompasses data from 664 firms $(4,433$ firm years). This sample (in the following, Sample II) includes firms with at least four continuous years of data because the analysis of consequences of control transfers requires data on the year prior and the two years after change in ownership. In Section 3.2 we investigate whether dropping firms with fewer continuous years of data introduces a selection bias, particularly which variables are most likely to be affected.

The sample is fairly representative for the universe of large German corporations. Taking the number of all incorporated German firms in the year 1992 as a reference, coverage is high for listed firms $(66.6 \%)$, all of which are public corporations (Table 1). ${ }^{1}$ For non-listed firms, coverage is small for public corporations $(13.9 \%)$ and weak for private corporations $(0.03 \%)$. Controlling for firm size, the sample includes $48 \%$ of all public corporations with total sales exceeding 100 million DM, and more than three percent of large private corporations. This study does not distinguish between private and public firms because they

1 The database includes all firms listed on any German stock exchange that do not belong to the financial industry and industries under strict regulation such as utility, traffic, and telecommunications (see Appendix). 
are similar in many regulatory characteristics (e.g., liability status, publication requirements, and taxation). ${ }^{2}$ Industry coverage is sufficiently representative for manufacturing industries. There is also a significant number of firms operating in other industries, for example in wholesale trade and construction. Details on sample selection and data sources used are provided in the Appendix.

\subsection{Characteristics of entering and exiting firms}

In the following we examine whether our sample systematically excludes some type of firms. For example, if poor performance increased the likelihood of firm failure or takeover, the sample could contain systematically fewer poorly performing firms. This would bias any observed correlation of performance and the likelihood of a control transfer. We choose two approaches to analyze sample composition. First, we check whether Sample II, which is used for the analysis of causes and consequences of control transfers (Section 5), systematically excludes some type of firms. Second, we examine what kind of firms enter and exit the full sample (Sample I) during the years 1987-1994.

We compare Sample I with Sample II, which contain firms with at least two and at least four continuous years of data, respectively, on some key firm characteristics, separately for listed and non-listed firms (Table 2). For nearly all firm characteristics we find no significant differences except for ownership concentration being significantly smaller in Sample II for non-listed firms. This could be due to the fact that Hoppenstedt, the data provider, strongly increased coverage of non-listed subsidiary companies in the early 1990s. As these firms typically show very high ownership concentration, Sample I contains relatively more firms with few observations and high concentration. Next, we compare firms with at least four continuous years of data (Sample II) with firms that have fewer than four observations. Again we find that for non-listed firms ownership concentration is smaller in Sample II. In addition, Sample II contains fewer non-listed firms with a large burden of debt, poor performance, and smaller firm size. For listed firms, we find no systematic difference between the two samples except for firm size, which is larger in Sample II.

Table 3 shows whether firms that enter Sample I after 1987, the first year of the sample, or exit before 1994, the last year of the sample, are systematically different from other firms. For firms entering in year $t$, the comparison group is firms in year $t$ that are in the sample at least since year $t-1$. Vice versa, for firms exiting at the end of year $t$, the comparison group is firms in year $t$ that are still in the sample in year $t+1$. On average across all sample years, we find that non-listed firms show higher shareholder concentration, a larger burden of debt, and smaller firm size when they enter the sample. In addition, a comparably large fraction of entering non-listed firms reports earnings losses. Exiting non-listed firms are also smaller in size and more indebted than firms remaining in the sample. For listed firms we find that ownership concentration is larger, firm size is smaller, and performance is better when they enter the sample. Exiting listed firms are smaller in size. All results are qualitatively similar at the median (not reported).

The lesson from this sample composition analysis is that comparing sample averages of shareholder concentration year by year could be misleading because entering firms show,

2 One major difference between private $(\mathrm{GmbH})$ and public corporations $(\mathrm{AG})$ is that in private corporations the general meeting of shareholders can give instructions to management, but not in public corporations. Therefore, management could in principle be under tighter control in $\mathrm{GmbH}$ firms. This difference is unlikely to be of major relevance in our sample because ownership concentration is high for both types of firms. 
on average, higher concentration than firms already in the sample. Regarding the other characteristics, it is possible that Sample II is somewhat biased towards well-performing firms, however only for non-listed firms. Overall, a systematic bias due to sample attrition appears to be unlikely because, with the exception of firm size, exiting firms are not significantly different from other sample firms. This result could be expected because $60 \%$ of sample exits are cases of non-reporting due to name changes, and not due to failure or acquisition (see Appendix).

\subsection{Concept of control}

A source of dispute in early empirical studies on the relation between ownership and performance has been the definition of corporate control. One approach is to classify companies into either manager-controlled or owner-controlled firms (Short, 1994). This classification is to some extent arbitrary. Using continuous ownership variables based upon the fraction of share ownership or voting rights is a more precise measure of direct ownership. However, both approaches do not capture the effects of complex ownership structures. For Germany such analysis of direct ownership is therefore not sufficient. By using the concept of ultimate ownership it becomes possible to define corporate control within complex ownership structures. This requires the analysis of control chains throughout several levels and the identification of a most powerful ultimate owner if any such exists. We use the concept of ultimate ownership in this study.

The identification of the ultimate owner for each firm is based upon German corporate law and involves two steps. First, we identify the ultimate owner for each direct shareholder using the following three rules. Rule 1 (strong ownership rule): A chain of control is pursued to the next level if the shareholder being analyzed is owned to $50 \%$ or more by a shareholder on the next level, while all other shareholders on the next level own less than $50 \%$. Rule 2 (weak ownership rule): If rule 1 does not apply, a chain of control is pursued to the next level if the shareholder being analyzed is owned to $25 \%$ or more by a shareholder on the next level, while all other shareholders on the next level own less than $25 \%$. Rule 3 (stop rule): If neither rule 1 nor rule 2 applies, a chain of control is not pursued further. These rules guarantee that no more than one ultimate owner is identified for each direct shareholder. Note that if a shareholder has split his ownership stake in a particular company into several smaller stakes, for example into two blocks of $50 \%$ held by two subsidiary firms, we combine these smaller stakes into one single block. We set the first cutoff point at $50 \%$ because German law allows an investor owning $50 \%$ of all shares to appoint management. ${ }^{3}$ The second cutoff point is set at $25 \%$ because an investor owning $25 \%$ of the shares has the right to veto decisions. In a second step in determining the ultimate owner for each sample firm, we apply the three rules to all direct shareholders. This allows to identify one single shareholder that is in ultimate control. When no single shareholder fulfills the criteria, this firm is seen to have no ultimate owner.

For illustration, consider the example of Dornier Aeronautics GmbH, a non-listed mediumsized firm in the aeronautics industry (Fig. 1). In the year 1992 it is one hundred percent owned by Dornier GmbH, the direct shareholder (level 1). In turn, Dornier GmbH is owned by the Dornier family (42.4\%) and by Deutsche Aerospace AG (57.6\%)(level 2). This latter firm is part of the Daimler-Benz AG conglomerate structure, being owned with $83.0 \%$

3 A $50 \%$ majority is sufficient to dismiss management after their regular period of office. But a majority of $75 \%$ is required to dismiss management during its period of office ( $\$ 103$ (1) AktG). 
by the automobile giant (level 3). Daimler-Benz AG itself is in the hands of Deutsche Bank AG (28.2\%), Mercedes Automobil-Holding AG (25.2\%), and the Emirate of Kuwait (14\%). The rest of the shares is dispersed. Applying our concept of control, we find a continuous chain of majority stakes between Dornier Aeronautics GmbH and Daimler-Benz AG, but several shareholders owning minority stakes larger than $25 \%$ in Daimler-Benz AG. Hence, we identify Daimler-Benz AG on the third level in the ownership structure as the ultimate owner of Dornier Aeronautics GmbH.

In addition to our concept of control, two main alternatives of how to define ultimate ownership are conceivable. One possibility is to pursue each ownership chain to its end, multiply the individual share blocks along the way, and compare the shareholders at the end of each chain by size of the resulting product of ownership blocks. In the above example this implies that Dornier Aeronautics $\mathrm{GmbH}$ would be ultimately owned by the Dornier family (42.4\%), Deutsche Bank AG (13.5\%), Mercedes Automobil Holding AG (12.0\%), the Emirate of Kuwait (6.7\%), and many small shareholders. Hence, Dornier Aeronautics $\mathrm{GmbH}$ would be seen to have at least four ultimate owners, each controlling Dornier Aeronautics GmbH with a certain probability. Another alternative is to assume that shareholders on higher levels of the ownership structure cannot influence decisions at the base level, for example due to information asymmetries or transaction costs. In this case Dornier $\mathrm{GmbH}$ is identified as the single ultimate owner.

Both alternatives have weaknesses. For the first alternative, information on the complete control chains of all direct shareholders is required. In most cases this information is available only for the largest shareholders. The second alternative depends on the assumption of complete dilution of control in pyramid structures. The large number of conglomerate firms in Germany with up to six or more layers of ownership suggests that pyramids are attractive forms of organization. Hence, control is unlikely to be fully diluted in pyramids. Our concept of control overcomes these weaknesses and combines advantages of both alternatives: clear identification of one single ultimate owner and the incorporation of complex ownership structures.

Our concept of control could be subject to potential bias because it is based on officially reported ownership rights instead of voting rights. ${ }^{4}$ Ownership rights do not need to coincide perfectly with voting rights. There are two main reasons for this. First, shares might have voting caps or carry multiple voting rights. Second, shares that are officially reported as dispersed might be under de facto control of banks because the German system of proxy voting gives banks the right to execute voting rights of deposited shares. Unless shareholders have given instructions, banks can multiply their influence this way. We believe that these weaknesses are unlikely to produce a systematic bias. Although legal during 1987-1994, limitations on voting rights do not seem to be widespread. Gorton and Schmid (2000) report that only 14 of the largest German firms had voting rights restrictions. Hence, in the vast majority of sample firms voting rights do coincide with ownership rights. As for proxy voting, recent evidence suggests that proxy voting is extremely unlikely to enhance German banks' voting power considerably (Edwards and Nibler, 2000). In addition, only few of our sample firms have a widely dispersed shareholder base, which is the precondition for bank voting power based on proxy rights. Hence, proxy voting is

4 Note that information on voting rights, as provided by the German Securities Exchange Commission (BAWe) and used in the study of Becht and Böhmer (2000), is preferable to pure ownership information. But this information is available only from 1996 onwards, and the methodology applied by the BAWe to attribute voting rights in complex ownership structures has serious drawbacks, as shown by Becht and Böhmer. 
unlikely to significantly bias our concept of control. We recognize, however, that investors identified as ultimate owners at higher levels in the ownership structure might also be subject to proxy voting by banks.

\section{Frequency of control transfers}

In this section we describe the frequency of control transactions in Germany as well as the type of buyers and sellers of control blocks. We analyze changes in aggregate measures of ownership (Section 4.1) and changes in individual shareholders (Section 4.2). We show that ownership structures are not constant over time.

\subsection{Evidence based on aggregate measures}

If concentration of ownership changes over time, this can be a first indication that ownership structures are not constant. Table 4 examines this issue for three measures of concentration. We consider the size of the largest block, the sum of the three largest blocks, and the fraction of firms that are under ultimate control according to our concept of control. Table 4 reports average concentration over the years 1987-1994.

Table 4 shows that ownership concentration is large, irrespective of the measure applied. For listed firms, the average size of the largest block is $60.6 \%$, and for non-listed firms it is even larger with $85.9 \%$. The figure for listed firms closely resembles the figure of $58.9 \%$ reported by Becht and Böhmer (2000), which is based on voting rights and calculated as the average for all listed firms in 1996. The similarity of these two figures suggests that the concept of control as applied in this study is indeed a suitable methodological tool to reconstruct voting hierarchies based on information of direct ownership rights. Note also that the two other concentration measures are highly correlated with our measure of control.

Furthermore, Table 4 suggests that ownership concentration has been increasing during the years 1987-1994. While the average size of the largest block in listed firms is $53.1 \%$ in 1987 , it constantly increases to $61.9 \%$ in 1994 . An analogous increase can be observed for non-listed firms. One reason for increasing average concentration could be that old shareholders or incoming new shareholders purchase shares from other shareholders holding smaller stakes. But as argued in Section 3.2, this observed increase could also be an artefact because firms entering the sample show, on average, higher concentration than firms already in the sample. The case of ownership concentration illustrates that it can be difficult to infer changes in disaggregate measures from changes in aggregate measures.

Another aggregate figure commonly used to describe ownership structures is the distribution of shares controlled by different shareholder types. Following the empirical literature, we define five shareholder types: individuals, financial firms (banks, insurance companies, and investment funds), non-financial firms, government, as well as dispersed shares. For individuals, we distinguish between directors (insiders) that play a particular role in governing a corporation and individuals not related to the firm. Partnerships are included in the category 'individuals' because in Germany managers of these firms are usually identical with their owners. Hence no additional agency problem exists. 
Table 5 classifies all direct share blocks, which are assigned to the type of their ultimate owner, into these five ownership categories. For listed firms, we find that individuals $(36.8 \%)$ and non-financial firms (24\%) ultimately control the largest fraction of shares. Financial firms own about nine percent of shares, with banks owning a larger fraction than insurance companies, with $7.3 \%$ and $1.8 \%$ respectively (not tabled). About $32 \%$ of the shares of listed firms are not owned by any large shareholder (dispersed), and about 10\% for non-listed firms. The role of banks as ultimate owners appears to be limited compared to the central role they are often assumed to play in corporate Germany. But as argued in Section 3.3, the influence of banks is hard to capture based solely on shares directly owned because the German system of proxy voting potentially enhances their influence. A theoretical upper limit of bank voting power can be calculated by attributing all dispersed shares to banks. For listed firms, according to Table 5 this would enable German banks to cast votes for at most about $39 \%$ of all shares in listed firms.

Similar to concentration of ownership, a changing distribution of shares across shareholder types could also indicate changes in ownership structure. Examining sample averages year by year we find that the fraction of shares controlled by non-financial firms and individuals increases, for non-listed firms and listed firms respectively. At the same time, the fraction of dispersed shares declines considerably for both listed and non-listed firms. One interpretation could be that dispersed shares are purchased by either individuals or non-financial firms. But as shown in Section 3.2, entering firms typically have a lower fraction of dispersed shares. Again this suggests that aggregate measures are less useful to determine changes in disaggregate measures.

\subsection{Evidence based on changes in individual shareholders}

In contrast to evidence based on ownership changes between shareholder categories, as discussed in the previous section, this section takes into account ownership changes within shareholder categories. With data on individual shareholders it is possible to overcome the weaknesses of evidence based on aggregate measures of ownership, which result from changing sample composition. Applying our concept of control, we identify the ultimate owner of each direct shareholder. Then we compare the names of those ultimate owners year by year and aggregate annual changes in individual shareholders into three categories: (1) the increase of shares held by new shareholders, (2) the increase of shares held by old shareholders, and (3) the decrease of shares held by old shareholders.

For better illustration, consider the following example (Fig. 2). In the year 1990, Boge AG, a large non-listed firm in the rubber industry, is owned by four large shareholders. Applying the concept of control, we identify Carlo de Benedetti as the ultimate owner of Boge AG. In the year 1991, Mannesmann AG becomes the new ultimate owner of VDO Adolf Schindling AG, a direct shareholder of Boge AG. For Boge AG this implies a decrease of $20.1 \%$ by an old shareholder (the Schindling-Rheinberger family), and an increase of $20.1 \%$ by a new shareholder (Mannesmann AG). Note that de Benedetti remains the ultimate owner of Boge AG. In the year 1992, Mannesmann AG acquires almost all shares of Boge AG, becoming its new ultimate owner. This implies a decrease of $74.3 \%$ by old shareholders, and an increase of $80.4 \%$ by an old shareholder.

Table 6 shows that in listed firms, on average in any given year, $4.4 \%$ of shares are purchased by new shareholders during 1987-1994. Old shareholders increase their invest- 
ment by $1.5 \%$, and old shareholders decrease their investment by $5.4 \% .^{5}$ For non-listed firms, average figures are very similar. Statistically, the difference between both types of firms is not significant. Hence, there is a significant market for large share blocks in Germany, both for listed and non-listed firms.

An interesting feature of this market is that there is large variation over time (Table 6). During the period of observation, boom times of large block trading are the years 1987, 1989, 1990, and 1994. This variation is reflected both in increases by new shareholders and decreases by old shareholders, and both for listed and non-listed firms. Therefore it is unlikely to be driven by variation in the fraction of dispersed shares. One reason for increased transaction activity is privatization. In 1990, the year of German reunification, privatization of formerly state-owned enterprises accounts for about ten percent of all transactions. But also the purchase of large conglomerates with many subsidiaries is important. When Feldmühle Nobel AG was acquired by VEBA AG in a hostile takeover during the year 1989, VEBA AG also became the ultimate owner of another four nonlisted firms in our sample. And when Metallgesellschaft AG came into trouble in 1993, it had to sell five subsidiaries contained in the sample to other industrial companies.

In the remaining part of this section we analyze these block transactions in depth. First, we look at their frequency and the size of traded blocks. Second, we examine block trading with respect to the identity of block traders. The sample encompasses 2,422 firm years for non-listed firms and 2,460 firm years for listed firms. This is the total number of cases in which block trading could occur. For listed firms, in 258 cases $(10.5 \%$ on average in any given year) we observe that a block is purchased by a new shareholder. For non-listed firms, the respective rate of block purchases is lower with $7.3 \%$. Table 7 shows the size distribution of blocks purchased by new shareholders. For listed firms, the purchased block is equal or exceeds $50 \%$ in 107 cases (41.5\%). In 62 cases, the new shareholder purchases $25 \%$ or more but less than $50 \%$. In sum this means that in 169 cases $(65.5 \%)$ an incoming shareholder acquires a stake of at least $25 \%$. This strongly suggests that new shareholders come in because they want to take over control of the respective firm.

To put these results into perspective, we compare the frequency of block purchases with results from previous studies. For listed firms, we find that a new shareholder purchases a block larger than ten percent in $9.9 \%$ of sample firms, on average in any given year. This rate of block purchases compares to $12.4 \%$ for Belgium (Renneboog, 2000) and 9.0\% for the UK (Franks et al., 1999). For the US, Bethel at al. (1998) report a rate of 6.6\% for blocks larger than five percent. Hence, the frequency of block transfers in Germany is similar to other countries. For non-listed firms, the respective annual rate is $7.0 \%$; however, no comparable figures from other countries are available.

As exemplified by the case of Boge AG (Fig. 2), the transfer of a large block (partial firm sale) does not need to be associated with a transfer of control over the entire firm. An example of this is a new shareholder purchasing a large block, while the majority of shares remains in the hands of the ultimate owner. To identify transfers of control we check for name changes of the ultimate owner. We find that a change in control takes place in 205 cases in listed firms (8.3\% on average in any given year), and in 146 cases in non-listed firms (6.0\%). ${ }^{6}$ Hence, the frequency of control transfers is considerably higher

5 The sum of increases of old and new shareholders does not need to be equal to the decrease of old shareholders because free-floating shares are not counted as held by a blockholder.

6 Overall, $73.2 \%$ of sample firms do not experience any change in control. For about $20 \%$ of firms the ultimate owner changes once, for about six percent twice. Hence, several consecutive changes in control are not very likely. 
than suggested by the average size of blocks traded (Table 6), but lower than suggested by the number of blocks traded. We conclude that not all block transfers lead to control transfers, but that a large part does.

To see whether a particular shareholder type dominates control transfers we examine the transaction partners more closely. For listed firms, we find that most control blocks are sold by non-financial firms $(33.2 \%)$ and individuals $(29.3 \%)$. In turn, the largest number of control blocks is purchased by non-financial firms (41.5\%) and individuals $(25.9 \%)$. Compared to the fraction of listed firms under ultimate ownership of non-financial firms $(28.6 \%)$ and individuals $(42.4 \%)$, it becomes clear that non-financial firms trade control blocks more often than would be expected by their frequency as ultimate owners. In comparison with all other shareholder types, non-financial firms are the most active traders of control blocks. For non-listed firms, non-financial firms buy an even larger fraction of control blocks $(56.8 \%)$, more than three times the fraction individuals purchase.

\section{Causes and consequences of control transfers}

In the following we analyze the causes and consequences of changes in ultimate ownership. The aim is to test the hypotheses lined out in Section 2. All results derived in this section are based on bivariate analyses, and any causal interpretation we give to correlations between variables is in the sense of Granger (1969).

To identify the causes and consequences of control transfers, we compare firms that experience a change in ultimate ownership with firms that do not experience such a change in any of the sample years, based on various firm characteristics. Specifically, we calculate the mean of each firm characteristic for the year of control change (year 0) as well as for the two years preceding (year -1, year -2) or following this change (year 1, year 2 ). Our benchmark are firms that do not experience a control transfer in any of the sample years, or more exactly, the characteristics' average over all sample years for these firms. ${ }^{7}$ The analysis is based on Sample II, which contains firms with at least four continuous years of data.

\subsection{Causes of control transfers}

To examine the causes of control transfers, we compare firms on measures of ownership structure, capital structure, size, and performance. Tables 8 and 9 investigate the differences between firms with (columns 2 and 4) and without (columns 1 and 3) a change in control, separately for listed and non-listed firms. Three consecutive years are considered: the year in which the change in ultimate ownership occurs (year 0 ), and the two years prior to this change (year -1 and year -2).

Table 8 shows that firms experiencing a change in control differ significantly from firms not experiencing such a change on a range of characteristics. These differences are observed for listed as well as non-listed firms; often it is only the level of the respective firm characteristic that differs between both types of firms. We find that ownership concentration is significantly smaller for firms in which the ultimate owner changes. For listed firms, one year prior to the change in control the average size of the largest block is $50.7 \%$, but

7 All results are qualitatively similar when we compare firms at the characteristics' median instead. 
$62.7 \%$ in firms without a transfer of corporate control. For non-listed firms, the difference in ownership concentration is also significant, but the average size of the largest block is much larger. Similarly, we find that changes in control are less likely to occur for firms that are under control of an ultimate owner than for firms that are not under control of an ultimate owner. This is strong empirical support for Hypothesis H1: Changes in ultimate ownership are less likely for firms with high ownership concentration.

We also find strong support for Hypothesis H2 that highly leveraged firms are more likely to experience a change in control. Listed as well as non-listed firms for which we observe a change in ultimate ownership show a significantly larger burden of debt than other firms. This result is robust when interest coverage or the borrowing ratio are used as alternative measures of leverage. Regarding complexity of ownership, the results in Table 8 indicate that the level at which the ultimate owner is located is important. For non-listed firms, this level is significantly lower prior to a change in ultimate ownership. Therefore non-listed firms controlled through pyramids are less likely to experience a change in control. In turn, for listed firms the level of control is significantly higher after the change. This suggests that listed firms tend to be controlled through a pyramid after a change in control. To investigate how changes in ownership are related to cross ownership, we define a variable indicating whether a sample firm is ultimately controlled by a firm belonging to the well-known web of financial and non-financial German firms, similar to Wenger and Kaserer (1998). This web consists of the five largest commercial German banks, two large insurance companies, as well as large non-financial firms such as Linde AG, Siemens AG, and VIAG AG. The analysis shows that firms experiencing a change in ultimate ownership are less likely to be under control of a web firm (not tabled), but the difference is not statistically significant. Summarizing, there is evidence supporting Hypothesis $\mathbf{H 3}$ that complex ownership structures make a change in control less likely, but only for non-listed firms. In turn, listed firms tend to become integrated in pyramids after a change in ownership.

Larger firms, whether listed or not, are significantly less likely to be exposed to a change in ultimate ownership (Table 8). For example, we find that listed firms in which the ultimate owner does not change are about $80 \%$ larger in terms of sales than listed firms experiencing a change in control. Analogous differences are found when using total assets or the number of employees as measures of firm size. This is strong support for Hypothesis H4. Concerning the role of insider ownership, insiders (executive and non-executive directors) own a significantly lower fraction of shares in listed firms that experience a change in control. In addition, insider ownership falls considerably in listed as well as non-listed firms when ultimate ownership changes. For example, in non-listed firms it drops from an average of $10.3 \%$ to $5.4 \%$. An $F$-test shows that this difference is statistically significant at the 0.10 level. This indicates that insiders tend to sell out in control transactions. Hence, for listed firms there is strong evidence supporting Hypothesis H5: Changes in ultimate ownership are less likely when insider ownership is high.

As a last cause of control changes we consider performance. To check for robustness we examine several measures of performance: return on assets (ROA), return on equity (ROE), the change in ROA, the change in ROE, the fraction of firms reporting an earnings loss, and annual stock market return. All measures except the loss indicator are corrected for median performance at the two-digit industry level. ${ }^{8}$

8 We also calculated performance relative to median returns in the same accounting year. For nonlisted firms, the obtained results suggest a stronger effect of poor performance on changes in ultimate ownership than the results reported in Table 9. 
Table 9 suggests that poor performance is not related to changes in ultimate ownership. Only listed firms that report an earnings loss are significantly more likely to experience a change in control. For non-listed firms we do not find evidence that performance is particularly poor before a change in control occurs. Accounting returns appear to be somewhat lower one year preceding the change; however, the difference in industry-adjusted performance to firms without a change in control is insignificant. Only in the year of control change performance of non-listed is significantly smaller. One reason for this lack of evidence regarding performance can be that our sample contains systematically fewer poorly performing non-listed firms (see Section 3.2). If poor performance makes a change in control more likely and these firms disappear from the sample due to a takeover, this will bias any observed relation between performance and the likelihood for a change in control towards zero. In summary, our data confirm Hypothesis H6, but only for listed firms with very poor performance. This result does not necessarily stand in contrast to our finding that stock market returns are significantly higher one year before control changes. To the contrary, this might indicate that control transfers are anticipated and perceived as value-enhancing events.

\subsection{Consequences of control transfers}

In the following we analyze the consequences of control transfers. Again, we compare firms that experience a change in ultimate ownership with firms that do not experience such a change in any of the sample years. Effects on governance changes and corporate restructuring are discussed in Section 5.2.1 and effects on performance in Section 5.2.2.

\subsubsection{Governance changes and corporate restructuring}

Table 10 describes how management turnover, asset divestitures, employment growth, and labor costs evolve in firms that experience a change in control. All figures are calculated for the year of ultimate ownership change (year 0), the two following years (year 1 and year 2 ), and the year prior to the change (year -1$)$.

For listed and non-listed firms we observe a strong increase in management turnover. For example, for listed firms that experience a change in control CEO turnover rates more than double from $10.2 \%$ in the year preceding the change to $21.1 \%$ in the year of change (Table 10). This turnover rate is significantly above average CEO turnover in listed firms without a change in ultimate ownership. For non-listed firms we find a similar increase in CEO turnover following the control change. The increase in management turnover is consistent with Denis and Sarin (1999) who find that US firms experiencing large increases or decreases in insider ownership show CEO turnover rates of 15\%-20\%; in contrast, small changes in ownership are associated with turnover rates of only $8 \%$. Hence, a CEO turnover rate of $14 \%$, which we find for German listed firms not experiencing a change in control, is comparatively high. Partially this difference might be explained by the fact that our turnover data include CEOs leaving the board voluntarily. Unfortunately, for Germany no consistent data are available on voluntary or forced management resignation.

Similar to CEO turnover, the replacement rate of executive directors increases considerably following control transfers (Table 10). For the supervisory board, which in Germany is separated from the management board, we find turnover rates for the chairman and the other board members (not tabled) that are above those reported for the management 
board. These findings strongly support Hypothesis $\mathbf{H} 7$ that changes in ultimate ownership are followed by increases in management (and supervisory) board turnover.

Asset divestitures also increase in control transfers; this increase is significant for sales of fixed assets, but only for listed firms (Table 10). Specifically, for listed firms we find that sales rates of fixed assets increase from $6.9 \%$ in year -1 to $8.8 \%$ in year 0 . The difference in the rate of asset sales to firms without a change in control is significant at the 0.05 level. For non-listed firms, we also observe an increase in sales of fixed and financial assets, but the difference to firms without a change in ultimate ownership is insignificant. Concerning employment, we find that in the second year after the control transfer the average growth rate of employment is negative for listed and non-listed firms, but the difference in growth rates between firms with and without a change in control is significant only for listed firms. Hence, employee layoffs increase, but not before two years after the change in control. This time lag suggests that adjustment costs play an important role in reorganizing a firm.

Whereas there is evidence for asset divestitures and layoffs, we find no evidence of cost cutting. On the contrary, labor costs per employee do not decline, but increase after a change in ultimate ownership. This suggests that the new owner is working to improve incentives for employees. Overall, the empirical evidence on corporate restructuring supports Hypothesis $\mathbf{H 8}$, but only for listed firms.

\subsubsection{Effects on performance}

As a last consequence we examine the impact of control changes on performance. If there is any impact, then it should be most visible for firms that previously experienced a decline in performance. The analysis proceeds in two steps. First, we compare firms that perform worse than their industry peers in year -1 and experience a change in control in year 0 , with median industry performance. Table 11 reports the difference in performance, starting with the year of poor performance (year -1) through the three following years (columns 1 and 2). For robustness, various performance measures are used. We recognize that requiring four continuous years of data potentially induces a selection bias. As shown in Section 3.2, this does not cause a selection bias for listed firms. For non-listed firms, our sample contains systematically fewer poorly performing firms; but this should bias any observed relation between control transfer and performance improvement towards zero.

In the second step of analysis, we compare firms that perform worse than their industry peers in year -1 and experience a change in control in year 0 , with those that also perform worse than their industry peers in year -1 but did not experience such a change in any year. The reason is that selecting only poorly performing firms to examine performance improvements could induce a second type of selection bias, particularly if there is mean reversion in our performance measures. If this is the case, performance should improve irrespective whether followed by a change in control or not. Table 11 reports the difference in performance, starting with the year of poor performance (year -1) through the three following years (columns 3 and 4). Poor performance is defined as the respective measure being below its median in the same two-digit industry in year -1 .

Table 11 suggests that performance of listed and non-listed poorly performing firms adjusts to the industry benchmark after they experience a change in control. For example, we find that industry-adjusted return on assets, which by definition is negative in year $-1(-4.8 \%)$, improves to $0.4 \%$ in the second year after the change in control. Comparing the levels of performance in year 2 and in year -1 we ascertain that performance improves 
significantly (difference in levels not reported). We find analogous results using alternative measures of performance.

The observed improvement in performance does not necessarily have to be caused by a change in control. As noted above, it might be due to mean reversion. Table 11 shows that for firms performing poorly in year -1 and experiencing a control transfer in year 0 the improvement in performance is stronger than for firms performing poorly in year -1 without a subsequent control transfer. However, this difference in performance improvement is insignificant. Hence, after taking into account potential bias resulting from mean reversion, we do not find evidence that performance improves particularly following control transfers. This result holds for listed as well as non-listed firms. We must reject Hypothesis H9. Note, however, that major improvements in performance might become visible only three or more years after a change in control. Unfortunately, our data set is too small for this exercise because requiring five or more continuous years of data would leave too few observations.

\section{Conclusions}

This paper sheds light on the market for corporate control in Germany. It provides evidence on the size of this market, as well as the causes and consequences of control transfers. We find that Germany has an active market for large share blocks. For listed firms, a new shareholder purchases a block larger than ten percent in $9.9 \%$ of sample firms, on average through the years 1987-1994. This rate of block purchases compares to $12.4 \%$ for Belgium (Renneboog, 2000) and 9.0\% for the UK (Franks et al., 1999). For the US, Bethel et al. (1998) report a rate of $6.6 \%$ for blocks larger than five percent. Hence, the frequency of block trades in Germany is similar to other countries. For non-listed firms, the respective rate is $7.0 \%$; no comparable figures from other countries are available. The vast majority of block trades leads to changes in ultimate ownership (control transfers). Taking into account only block trades that lead to a control transfer, we find annual rates of $8.3 \%$ for listed firms and $6.0 \%$ for non-listed firms. The most active traders of control blocks are non-financial firms and to a lesser extent individuals.

We find that control transfers are more likely for firms with high leverage, but less likely for larger firms and firms with high concentration of ownership. In addition, high insider ownership and complex ownership structures make control transfers less likely for listed and non-listed firms, respectively. Our finding regarding insider ownership is consistent with evidence from the US (Barber et al., 1995) and Canada (St-Pierre et al., 1996) that high director ownership is associated with an increase in resistance to ownership changes. In contrast, our findings regarding performance indicate that the German market for corporate control works differently compared with the US. Case-study evidence collected by Denis and Sarin (1999) suggests that poor performance is often the impetus for the purchase of large blocks. For Germany we find that control changes are related to poor performance as well, but only when performance is very poor and only for listed firms. This suggests that changes in ownership tend to occur when the firm's regular governance mechanisms (such as board control) fail.

Changes in ultimate ownership are followed by increased management and supervisory board turnover. For listed firms, asset divestitures and employee layoffs increase after a change in control. In contrast, there is no evidence of cost cutting as labor costs per 
employee tend to increase after control transfers. Regarding management turnover, our results are consistent with evidence from Belgium (Renneboog, 2000) and the US (Denis and Sarin, 1999). Concerning asset restructuring, a similar impact has been reported for the US (Bethel et al., 1998; Denis and Sarin, 1999; Denis and Kruse, 2000). Our results have implications for the speed of organizational change. Kole and Lehn (1999) show for the US airline industry that internal governance structures adjust gradually after deregulation. In contrast, we find that CEO turnover occurs rapidly after a change in ownership. Hence, changes in external governance structures serve as a catalyst for organizational adaptation.

In contrast, we do not find evidence that control changes are followed by improvements in performance, irrespective whether we measure performance by accounting- or market-based returns. This result is at odds with evidence from the US where performance improves after major changes in ownership (Bethel et al., 1998; Denis and Kruse, 2000).

Furthermore, we find that important causes and consequences of control transfers are different for listed and non-listed firms. Specifically, complex ownership structures limit control changes for non-listed firms. This indicates that empirical studies examining only listed firms tend to underestimate the impact of ownership complexity on control transfers. Regarding restructuring, we cannot find evidence of asset divestitures or layoffs for non-listed firms. This indicates that studies focusing on listed firms tend to overestimate the impact of control transfers on restructuring. Our finding that control transfers are preceded by poor performance only for listed firms suggests that factors other than performance motivate ownership changes in non-listed firms. Whether this is so for other countries as well, or which factors this could be are open questions. The main lesson is that empirical analyses should consider listed as well as non-listed firms because important aspects of the control transfer process work differently. Table 12 summarizes the empirical evidence gathered in this study. Note that any causal relation we give to correlations between variables is in the sense of Granger (1969). A possible extension of the present study is to examine control transfers in a multivariate framework.

From the methodological point of view, the existence of a significant market for corporate control has important implications for the design of empirical studies on corporate governance. As ownership structures are not stable over time, it is not sufficient to use cross-section data on ownership to explain variation in performance because any unobserved variation in ownership will be included in the error term (see also Denis and Sarin, 1999; Börsch-Supan and Köke, 2000). But correlation of the error term with (observed) cross-section data on ownership will cause coefficients to be biased and inconsistent. Likewise, explaining firm performance without data on ownership, but instead applying fixed-effect models to account for unobserved firm heterogeneity will also result in biased and inconsistent coefficients, because unobserved (ownership) variables are not fixed over time. Hence, results of previous studies using either cross sections of ownership data or no ownership data are likely to be biased.

Finally, one policy implication of this study is that the currently proposed new Law on Securities Purchases and Takeovers will not cover a large part of control transactions in Germany because it extends only to listed firms. But the frequency of control transfers is similar for listed and non-listed firms. Prudent regulation governing the process of changes in corporate ownership will become even more urgent when from the year 2002 on German corporations are allowed to sell their substantial stakes in other companies without taxation of the realized profits. This measure is expected to increase the frequency of acquisitions and divestitures considerably. 


\section{Appendix}

The first main pillar of data comes from Hoppenstedt's Balance Sheet Database (BSD). An important feature of this data source is that it contains information on listed and nonlisted corporations, both public (AG) and private $(\mathrm{GmbH})$ (see also Table 1). We take 1986 as the starting year because a change in disclosure rules hinders comparability of the annual reports before and after the year $1986 .{ }^{9}$ The last year of the sample is 1994 because publication of our main source of ownership data has been discontinued in this year. For the period 1986-1994, BSD contains 5,222 firms (22,732 firm years) for which consolidated balance sheet data are available (Table 13). We eliminate firms from the utility, traffic, and telecommunications industries because they were still predominantly government-owned during the period of observation. As a matter of comparability, we also eliminate firms that primarily operate in the banking and insurance business, while operating little in non-financial activities. Selection by industry causes 1,752 firm deletions.

The second main pillar - data on ownership structures - is obtained from annual reports published by Bayerische Hypotheken- und Wechsel-Bank (in short, Hypobank). These reports contain information on direct ownership of common stock (Stammaktien) for all listed German corporations. In addition, Hypobank provides information on direct ownership of common stock for large non-listed corporations (Stammaktien for the non-listed $\mathrm{AG}$ and Gesellschafteranteile for the $\mathrm{GmbH}$ which cannot be listed). Hypobank reports the size and the name of a direct owner when the size of the ownership block exceeds five percent. In general, ownership rights as reported by Hypobank correspond to voting rights (see Section 3.3).

Ownership information from Hypobank cannot readily be used in our analysis for three reasons. First, ownership information from Hypobank only refers to the direct level of owners. But this analysis requires to identify the ultimate owner of each sample firm. In contrast to Becht and Böhmer (2000), who rely on voting rights information provided by the German Securities Exchange Commission (Bundesaufsichtsamt für den Wertpapierhandel) ${ }^{10}$ this study reconstructs voting rights information in a bottom-up approach from information on direct ownership rights. Our concept of control, as outlined in Section 3.3, represents the methodological tool to achieve this aim. A second drawback is that Hypobank does not directly reveal ownership information on medium-sized non-listed firms. Other commercial data sources are also of little help because during our period of observation, non-listed firms have not been subject to strictly enforced disclosure requirements. Therefore, we construct the relevant ownership structures by searching the information on investments in subsidiaries and affiliated companies, which is given in the appendix to each company in Hypobank. To further enlarge our sample, we search the Mannheim Company Database (MUP) located at the ZEW in Mannheim. We thereby obtain ownership structures on many medium-sized non-listed firms, mainly for private corporations $(\mathrm{GmbH})$. Third, some firms changed their names during the period of observation, for example following takeovers or restructuring of conglomerates. Since changes in ownership are crucial to the data collection procedure, we adjust for name changes and obtain a panel on ownership structures through the years 1986-1994.

9 In 1985 several changes were introduced in German corporate law ( $\$ 289 \mathrm{HGB}$ ), most of them triggered by the European Community's Fourth Company Law Directive on the harmonization of national requirements pertaining to financial statements.

10 See Section 3.3 for a short discussion of this voting rights database. 
In consequence, we are left with ownership data for 1,485 firms (6,367 firm years). Because of missing values for important balance sheet items, another 30 firms must be eliminated. This selection procedure generates a sample of 1,455 firms (6,205 firm years) with at least one year of balance sheet and ownership data during the years 1986-1994. As this study examines changes in ownership we further eliminate 509 firms for which we have only one year of data. For almost all of these 509 firms the year 1994 is the single year. This is due to the fact that Hoppenstedt substantially increased firm coverage in 1994. The resulting sample which contains 946 firms (4,882 firm years) is labeled 'Sample I' in this study. For the analysis of causes and consequences of control transfers (Section 5) we require firms to display at least four continuous years of data. This generates 'Sample II' which contains 664 firms (4,443 firm years). In Section 3.2, we analyze whether limiting the sample to firms with several continuous years of data causes a selection bias. Table 13 summarizes the sample selection procedure.

To test for a potential sample selection bias, we collect data on the firms' survival status. For firms leaving the sample before 1994, information is obtained from the BSD and MUP databases and from telephone interviews. We find that 39 out of 65 firms that exit the sample before 1994 still existed in 1994 without a change in ultimate ownership, but simply changed their name or quit reporting due to reasons determined within the firm. In 11 cases operation was shut down due to liquidation or bankruptcy. In 14 cases the respective firm had been taken over by another entity. And in one case operation was shut down voluntarily. Hence, $60 \%$ of firm exits during the sample period are not related to firm failure or acquisition.

We recognize that the selection procedure of non-listed medium-sized firms does not generate a random sample of non-listed medium-sized German firms. Given that we include only medium-sized firms that are subsidiaries of conglomerates, our sample might be biased. For example, we lack medium-sized firms that are directly owned by families. But given the advantage of a smaller average firm size in the total sample we regard this as a necessary cost to be incurred. Further, if agency problems do exist, they should be most pronounced in our sample firms.

All variables used in this study are defined in Table 14 . 


\section{References}

Barber, B.M., Palmer, D., Wallace, J., 1995. Determinants of conglomerate and predatory acquisitions: evidence from the 1960s. Journal of Corporate Finance 1, 283-318.

Becht, M., Böhmer, E., 2000. Voting control in German corporations. Unpublished working paper. Universite Libre de Bruxelles.

Bethel, J.E., Liebeskind, J.P., Opler, T., 1998. Block share purchases and corporate performance. Journal of Finance 53 (2), 605-634.

Böhmer, E., 2000. Industry groups, bank control, and large shareholders: an analysis of German takeovers. Journal of Financial Intermediation 9 (2), 117-148.

Börsch-Supan, A., Köke, J., 2000. An applied econometrician's view of empirical corporate governance studies. Unpublished working paper. Centre for European Economic Research, Mannheim.

Cable, J., 1985. Capital market information and industrial performance: the role of West German banks. Economic Journal 95, 118-132.

Denis, D.J., Sarin, A., 1999. Ownership and board structures in publicly traded corporations. Journal of Financial Economics 52, 187-223.

Denis, D.J., Kruse, T.A., 2000. Managerial discipline and corporate restructuring following performance declines. Journal of Financial Economics 55, 391-424.

Edwards, J., Nibler, M., 2000. Corporate governance: banks versus ownership concentration in Germany. Economic Policy 15 (2), 237-267.

Fama, E.F., Jensen, M.C., 1983. Separation of ownership and control. Journal of Law and Economics 26, 301-325.

Franks, J., Mayer, C., 1990. Capital markets and corporate control: a study of France, Germany and the UK. Economic Policy 4 (10), 189-231.

Franks, J., Mayer, C., 1994. The ownership and control of German corporations. Unpublished working paper. London Business School, London, and University of Oxford, Oxford.

Franks, J., Mayer, C., 1995. Ownership and control. In: H. Siebert (Ed.), Trends in Business Organization. Mohr, Tübingen, pp. 171-200.

Franks, J., Mayer, C., 1998. Bank control, takeovers, and corporate governance in Germany. Journal of Banking and Finance 22, 1385-1403.

Franks, J., Mayer, C., Renneboog, L., 1999. Who disciplines bad management? Unpublished working paper. Oxford Financial Research Centre, Oxford.

Gorton, G., Schmid, F.A., 2000. Universal banking and the performance of German firms. Journal of Financial Economics 58, 29-80.

Granger, C., 1969. Investigating causal relations by econometric models and cross-spectral models. Econometrica 37, 424-438. 
Grossman, S.J., Hart, O.D., 1980. Takeover bids, the free-rider problem, and the theory of the corporation. Bell Journal of Economics 11, 42-64.

Holmström, B., Tirole, J., 1993. Market liquidity and performance monitoring. Journal of Political Economy 101 (4), 679-709.

Jarrell, G.A., Brickley, J., Netter, J., 1988. The market for corporate control: the empirical evidence since 1980. Journal of Economic Perspectives 2, 49-68.

Jenkinson, T., Ljungqvist, A., 2001. Hostile stakes and the role of banks in German corporate governance. Journal of Corporate Finance, forthcoming.

Jensen, M.C., 1988. Takeovers: their causes and consequences. Journal of Economic Perspectives 2, 21-48.

Jensen, M.C., Meckling, W.H., 1976. Theory of the firm: managerial behavior, agency costs, and ownership structure. Journal of Financial Economics 3, 305-360.

Jensen, M.C., Ruback, R., 1983. The market for corporate control. Journal of Financial Economics 11, 5-50.

Köke, J., 2001. New evidence on ownership structures in Germany. Kredit und Kapital 34 (2), 257-292.

Kole, S., Lehn, K., 1999. Deregulation and the adaptation of governance structure: the case of the US airline industry. Journal of Financial Economics 52, 79-117.

La Porta, R., Lopez-de-Silanes, F., Shleifer, A., 1999. Corporate ownership around the world. Journal of Finance 54 (2), 471-517.

Maksimovic, V., Phillips, G., 2001. The market for corporate assets: who engages in mergers and asset sales and are there efficiency gains? Journal of Finance 56 (6), forthcoming.

Mitchell, M.L., Mulherin, J.H., 1996. The impact of industry shocks on takeover and restructuring activity. Journal of Financial Economics 41, 193-229.

Mulherin, J.H., Boone, A.L., 2000. Comparing acquisitions and divestitures. Journal of Corporate Finance 6, 117-139.

OECD, 1998. Shareholder value and the market in corporate control in OECD countries. Financial Market Trends 69, 15-37.

Renneboog, L., 2000. Ownership, managerial control, and the governance of companies listed on the Brussels stock exchange. Journal of Banking and Finance 24 (12), 1959-1995.

Schwert, W.G., 2000. Hostility in takeovers: in the eyes of the beholder? Journal of Finance 55 (6), 2599-2640.

Shleifer, A., Vishny, R.W., 1992. Liquidation values and debt capacity: a market equilibrium approach. Journal of Finance 47 (4), 1343-1366.

Shleifer, A., Vishny, R.W., 1997. A survey of corporate governance. Journal of Finance 52 (2), 737-783. 
Short, H., 1994. Ownership, control, financial structure, and the performance of firms. Journal of Economic Surveys 8 (3), 203-247.

St-Pierre, J., Gagnon, J.M., Saint-Pierre, J., 1996. Concentration of voting rights and board resistance to takeover bids. Journal of Corporate Finance 3, 45-73.

Wenger, E., Kaserer, C., 1998. The German system of corporate governance - a model which should not be imitated. In: S.W. Black, M. Moersch (Eds.), Competition and Convergence in Financial Markets. Elsevier, Amsterdam, pp. 41-78.

Zingales, L., 1998. Survival of the fittest or the fattest? Exit and financing in the trucking industry. Journal of Finance 53 (3), 905-938. 
Table 1: Sample representativeness

Sample representativeness regarding coverage of non-listed and listed firms, separately by type of firm, taking 1992 as the year of reference. Column (1) shows the number of all German corporations, and column (2) the total number of sample firms (all incorporated), separately for listed/non-listed public (AG, KGaA) and non-listed private firms ( $\mathrm{GmbH})$. Column (3) provides the fraction of sample firms that are listed or non-listed, separately by legal form. And column (4) relates the number of sample firms to the number of all German corporations, separately by type of firm. Data on the number of all German corporations are obtained from Statistisches Bundesamt, Umsatzsteuerstatistik, Fachserie 14, Reihe 8.

\begin{tabular}{|c|c|c|c|c|c|}
\hline \multirow[t]{2}{*}{ Listing } & \multirow[t]{2}{*}{ Legal form } & \multirow{2}{*}{$\begin{array}{l}\text { All German } \\
\text { corporations }\end{array}$} & \multicolumn{3}{|c|}{ Sample firms (all incorporated) } \\
\hline & & & total & $\begin{array}{l}\text { in percent of } \\
\text { all sample firms }\end{array}$ & $\begin{array}{r}\text { in percent of all } \\
\text { German corporations } \\
\text { by type of firm }\end{array}$ \\
\hline & & (1) & $(2)$ & $(3)$ & (4) \\
\hline Yes & $\mathrm{AG}, \mathrm{KGaA}$ & 521 & 347 & $51.5 \%$ & $66.6 \%$ \\
\hline No & $\mathrm{AG}, \mathrm{KGaA}$ & 1,643 & 228 & $33.9 \%$ & $13.9 \%$ \\
\hline No & $\mathrm{GmbH}$ & 359,358 & 98 & $14.6 \%$ & $0.03 \%$ \\
\hline Total & & 361,522 & 673 & $100.0 \%$ & $0.2 \%$ \\
\hline
\end{tabular}


Table 2: Characteristics of firms with different number of observations

Characteristics of firms with different number of continuous years of data, separately for nonlisted and listed firms. Firms with at least four continuous years of data (Sample II, column 3) are compared with both firms with at least two continuous years of data (Sample I, column 1) and firms with less than four continuous years of data (column 2). Firms are compared at the mean of each firm characteristic. These include measures of ownership structure (size of largest share block, fraction of dispersed shares), capital structure (debt-to-assets ratio), firm size (total sales), and performance (return on assets (ROA), return on equity (ROE), change in ROA, change in ROE, the fraction of firms reporting an earnings loss, and annual stock market return). All performance measures except the loss indicator are corrected for median performance at the two-digit industry level. The test statistics are heteroscedastic $t$-tests of equal means. ${ }^{*}, * *, * * *$ indicates significance at the $0.10,0.05$, and 0.01 levels, respectively. The sample comprises 946 firms (Sample I), with 2,460 observations for listed firms and 2,422 observations for non-listed firms.

\begin{tabular}{lccc}
\hline \hline & $\begin{array}{c}\text { Firms with at least } \\
\text { two continuous years } \\
\text { of data (Sample I) }\end{array}$ & $\begin{array}{c}\text { Firms with less } \\
\text { than four continuous } \\
\text { years of data }\end{array}$ & $\begin{array}{c}\text { Firms with at least } \\
\text { four continuous years } \\
\text { of data (Sample II) }\end{array}$ \\
\hline Non-listed firms: & & & \\
Size of largest block & $85.9 \%^{* *}$ & $88.7 \%^{* *}$ & $84.4 \%$ \\
Fraction of dispersed shares & $9.3 \%^{* *}$ & $6.9 \%^{* *}$ & $10.5 \%$ \\
Debt-to-assets ratio & $39.0 \%$ & $45.9 \%^{* * *}$ & $38.2 \%$ \\
Return on assets (ROA) & $0.7 \%$ & $-4.4 \%^{* * *}$ & $0.8 \%$ \\
Return on equity (ROE) & $1.3 \%$ & $-9.5 \% * * *$ & $1.0 \%$ \\
Change in ROA & $0.0 \%$ & $-0.9 \%$ & $-0.2 \%$ \\
Change in ROE & $0.2 \%$ & $-3.6 \%$ & $-0.4 \%$ \\
Earnings loss & $14.1 \%$ & $29.8 \% * * *$ & $12.9 \%$ \\
Sales (in mio. DM) & $2,146.7$ & $371.4 * * *$ & $2,369.3$ \\
Number of observations & 2,422 & 181 & 2,012 \\
\hline Listed firms: & & & \\
Size of largest block & $60.6 \%$ & $65.9 \%$ & $60.6 \%$ \\
Fraction of dispersed shares & $31.5 \%$ & $32.1 \%$ & $31.5 \%$ \\
Debt-to-assets ratio & $41.3 \%$ & $41.8 \%$ & $41.2 \%$ \\
Return on assets (ROA) & $1.4 \%$ & $1.7 \%$ & $1.4 \%$ \\
Return on equity (ROE) & $1.6 \%$ & $-4.0 \%$ & $1.8 \%$ \\
Change in ROA & $-0.3 \%$ & $-1.8 \%$ & $-0.3 \%$ \\
Change in ROA & $-0.8 \%$ & $-8.9 \%$ & $-0.6 \%$ \\
Earnings loss & $9.3 \%$ & $11.1 \%$ & $9.3 \%$ \\
Stock market return & $2.4 \%$ & $-0.8 \%$ & $2.4 \%$ \\
Sales (in mio. DM) & $3,346.9$ & $590.5^{* * *}$ & $3,392.2$ \\
Number of observations & 2,460 & 18 & 2,421 \\
\hline \hline
\end{tabular}


Table 3: Characteristics of entering and exiting firms

Characteristics of firms entering the sample after 1987, the first year of the sample, or exiting the sample before 1994, the last year of the sample, compared with characteristics of firms that do not enter or exit the sample, separately for non-listed and listed firms. For firms entering in year $t$, the comparison group is firms in year $t$ that are in the sample at least since year $t-1$. Vice versa, for firms exiting the sample at the end of year $t$, the comparison group is firms in year $t$ that are still in the sample in year $t+1$. Firms are compared at the mean of each firm characteristic. These include measures of ownership structure (size of largest share block, fraction of dispersed shares), capital structure (debt-to-assets ratio), firm size (total sales), and performance (return on assets (ROA), return on equity (ROE), change in ROA, change in ROE, the fraction of firms reporting an earnings loss, and annual stock market return). All performance measures except the loss indicator are corrected for median performance at the two-digit industry level. The test statistics are heteroscedastic $t$-tests of equal means. ${ }^{*}, * *, * * *$ indicates significance at the 0.10, 0.05, and 0.01 levels, respectively. The sample comprises 946 firms (Sample I), with 2,460 observations for listed firms and 2,422 observations for non-listed firms.

\begin{tabular}{|c|c|c|c|c|}
\hline & \multicolumn{2}{|c|}{ Entry analysis } & \multicolumn{2}{|c|}{ Exit analysis } \\
\hline & $\begin{array}{r}\text { Firms } \\
\text { entering } \\
\text { in year } t\end{array}$ & $\begin{array}{l}\text { Firms in } \\
\text { sample at least } \\
\text { since year } t-1\end{array}$ & $\begin{array}{r}\text { Firms } \\
\text { exiting at end } \\
\text { of year } t\end{array}$ & $\begin{array}{l}\text { Firms still } \\
\text { in sample } \\
\text { in year } t+1\end{array}$ \\
\hline \multicolumn{5}{|l|}{ Non-listed firms: } \\
\hline Size of largest block & $89.1 \%$ & $85.7 \% * * *$ & $82.1 \%$ & $84.8 \%$ \\
\hline Fraction of dispersed shares & $6.9 \%$ & $9.5 \% * * *$ & $14.8 \%$ & $10.3 \%$ \\
\hline Debt-to-assets ratio & $43.8 \%$ & $37.9 \% * * *$ & $47.2 \%$ & $37.8 \% * *$ \\
\hline Return on assets (ROA) & $0.1 \%$ & $0.8 \%$ & $-0.4 \%$ & $1.0 \%$ \\
\hline Return on equity (ROE) & $1.7 \%$ & $1.3 \%$ & $-3.9 \%$ & $1.6 \%$ \\
\hline Change in ROA & $0.9 \%$ & $-0.2 \% *$ & $2.3 \%$ & $-0.4 \%$ \\
\hline Change in ROE & $1.7 \%$ & $-0.2 \%$ & $-1.3 \%$ & $-0.6 \%$ \\
\hline Earnings loss & $20.0 \%$ & $13.0 \% * * *$ & $19.3 \%$ & $12.3 \%$ \\
\hline Sales (in mio. DM) & $1,109.3$ & $2,430.3^{* * *}$ & 798.7 & $2,334.7 * * *$ \\
\hline Number of observations & 448 & 1,842 & 60 & 1,842 \\
\hline \multicolumn{5}{|l|}{ Listed firms: } \\
\hline Size of largest block & $67.3 \%$ & $60.8 \% * * *$ & $84.0 \%$ & $60.3 \% *$ \\
\hline Fraction of dispersed shares & $26.7 \%$ & $31.3 \% * *$ & $16.0 \%$ & $31.6 \%$ \\
\hline Debt-to-assets ratio & $41.0 \%$ & $41.6 \%$ & $41.1 \%$ & $41.2 \%$ \\
\hline Return on assets (ROA) & $4.6 \%$ & $1.2 \% * * *$ & $0.1 \%$ & $1.5 \%$ \\
\hline Return on equity (ROE) & $6.9 \%$ & $1.3 \% * * *$ & $0.2 \%$ & $1.8 \%$ \\
\hline Change in ROA & $0.4 \%$ & $-0.3 \%$ & $4.6 \%$ & $-0.6 \%$ \\
\hline Change in ROE & $0.4 \%$ & $-0.9 \%$ & $3.3 \%$ & $-1.6 \%$ \\
\hline Earnings loss & $3.5 \%$ & $10.1 \% * * *$ & $20.0 \%$ & $8.9 \%$ \\
\hline Stock market return & $12.7 \%$ & $4.5 \% * *$ & $6.7 \%$ & $4.1 \%$ \\
\hline Sales (in mio. DM) & 843.2 & $3,546.7^{* * *}$ & 28.6 & $3,325.3^{* * *}$ \\
\hline Number of observations & 171 & 2,094 & 5 & 2,094 \\
\hline
\end{tabular}


Table 4: Ownership concentration

Ownership concentration calculated as sample average in a given year for the period 19871994, separately for non-listed and listed firms. Measures of ownership concentration include the average size of the largest share block, the average sum of the three largest share blocks, and the fraction of firms for which an ultimate owner can be identified applying the concept of control. The size of the largest block and the sum of the three largest blocks are calculated at the direct level of ownership. The sample comprises 946 firms (Sample I).

\begin{tabular}{lrrrrrr}
\hline \hline & \multicolumn{3}{c}{ Non-listed firms } & \multicolumn{3}{c}{ Listed firms } \\
\cline { 2 - 7 } & $\begin{array}{r}\text { Size of } \\
\text { largest } \\
\text { block }\end{array}$ & $\begin{array}{r}\text { Sum of } \\
\text { largest } \\
\text { blocks }\end{array}$ & $\begin{array}{r}\text { Fraction of } \\
\text { firms with } \\
\text { ultimate owner }\end{array}$ & $\begin{array}{r}\text { Size of } \\
\text { largest } \\
\text { block }\end{array}$ & $\begin{array}{r}\text { Sum of } \\
\text { largest } \\
\text { blocks }\end{array}$ & $\begin{array}{r}\text { Fraction of } \\
\text { ultims with }\end{array}$ \\
\hline 1987 & $78.1 \%$ & $81.4 \%$ & $92.4 \%$ & $53.1 \%$ & $55.8 \%$ & $75.4 \%$ \\
1988 & $82.0 \%$ & $84.4 \%$ & $94.0 \%$ & $57.7 \%$ & $60.1 \%$ & $78.0 \%$ \\
1989 & $83.8 \%$ & $85.7 \%$ & $94.1 \%$ & $59.7 \%$ & $62.1 \%$ & $80.0 \%$ \\
1990 & $84.1 \%$ & $85.7 \%$ & $93.8 \%$ & $60.5 \%$ & $62.9 \%$ & $82.4 \%$ \\
1991 & $84.6 \%$ & $86.2 \%$ & $95.1 \%$ & $61.6 \%$ & $64.1 \%$ & $82.0 \%$ \\
1992 & $87.0 \%$ & $88.2 \%$ & $96.3 \%$ & $62.5 \%$ & $64.7 \%$ & $82.4 \%$ \\
1993 & $88.2 \%$ & $89.6 \%$ & $96.3 \%$ & $63.5 \%$ & $65.5 \%$ & $83.8 \%$ \\
1994 & $90.3 \%$ & $92.1 \%$ & $95.8 \%$ & $61.9 \%$ & $64.6 \%$ & $84.2 \%$ \\
\hline Average & $85.9 \%$ & $87.7 \%$ & $95.0 \%$ & $60.6 \%$ & $63.0 \%$ & $81.5 \%$ \\
\hline Correlation & 0.51 & 0.37 & 1.00 & 0.61 & 0.68 & 1.00 \\
with Control & & & & & & \\
\hline \hline
\end{tabular}

Table 5: Ownership of large share blocks by type of ultimate owner

Ownership of large share blocks by type of ultimate owner as sample average for the period 1987-1994, separately for non-listed and listed firms. For each share block on the direct level of ownership, the type of the ultimate owner is identified applying the concept of control. Second, for each firm the distribution of share blocks across five categories of the ultimate owner is determined, using block size at the direct level. Third, sample distribution of share blocks across categories is calculated as the average across all firm years. The five categories of the ultimate owner are: individuals (families, partnerships (Personengesellschaften), foundations), non-financial firms, financial firms (banks, insurance companies, investment funds), government authorities, and dispersed shares (shares not held in a block). Insiders are executive and nonexecutive directors. The sample comprises 946 firms (Sample I).

\begin{tabular}{|c|c|c|c|c|c|c|c|}
\hline & \multicolumn{2}{|c|}{ Individuals } & \multirow{2}{*}{$\begin{array}{r}\text { Financial } \\
\text { firms }\end{array}$} & \multirow{2}{*}{$\begin{array}{l}\text { Non-fin. } \\
\text { firms }\end{array}$} & \multirow[t]{2}{*}{ Government } & \multirow{2}{*}{$\begin{array}{r}\text { Dispersed } \\
\text { shares }\end{array}$} & \multirow[t]{2}{*}{ Total } \\
\hline & total & insiders & & & & & \\
\hline Non-listed firms & $30.7 \%$ & $12.0 \%$ & $9.2 \%$ & $48.6 \%$ & $4.7 \%$ & $9.3 \%$ & $100 \%$ \\
\hline Listed firms & $36.8 \%$ & $22.5 \%$ & $9.2 \%$ & $24.0 \%$ & $1.9 \%$ & $31.5 \%$ & $100 \%$ \\
\hline
\end{tabular}


Table 6: Purchases and sales of large share blocks

Average fraction of shares purchased by new shareholders (columns 1 and 4), purchased by old shareholders (columns 2 and 5), and sold by old shareholders (column 3 and 6) in any given year for the period 1987-1994, separately for non-listed and listed firms. First, the ultimate owner of each direct share block is identified. Second, the names of those ultimate owners are compared year by year and annual changes in individual shareholders are aggregated into the three categories. Third, for each of the three measures the average across all firm years is determined. The sample comprises 946 firms (Sample I).

\begin{tabular}{lrrrrrr}
\hline \hline & \multicolumn{3}{c}{ Non-listed firms } & \multicolumn{3}{c}{ Listed firms } \\
\cline { 2 - 7 } & $\begin{array}{r}\text { Increases } \\
\text { by new } \\
\text { shareholders }\end{array}$ & $\begin{array}{r}\text { Increases } \\
\text { by old } \\
\text { shareholders }\end{array}$ & $\begin{array}{r}\text { Decreases } \\
\text { by old } \\
\text { shareholders }\end{array}$ & $\begin{array}{r}\text { Increases } \\
\text { by new } \\
\text { shareholders }\end{array}$ & $\begin{array}{r}\text { Increases } \\
\text { by old } \\
\text { shareholders }\end{array}$ & $\begin{array}{r}\text { Decreases } \\
\text { by old } \\
\text { shareholders }\end{array}$ \\
\hline 1987 & $6.9 \%$ & $0.8 \%$ & $7.5 \%$ & $7.7 \%$ & $1.6 \%$ & $7.7 \%$ \\
1988 & $3.9 \%$ & $1.3 \%$ & $3.9 \%$ & $2.7 \%$ & $1.5 \%$ & $3.3 \%$ \\
1989 & $7.7 \%$ & $1.3 \%$ & $8.0 \%$ & $5.6 \%$ & $1.8 \%$ & $5.6 \%$ \\
1990 & $7.4 \%$ & $0.8 \%$ & $8.6 \%$ & $5.0 \%$ & $1.7 \%$ & $6.4 \%$ \\
1991 & $1.6 \%$ & $1.1 \%$ & $2.0 \%$ & $4.8 \%$ & $1.6 \%$ & $5.0 \%$ \\
1992 & $4.3 \%$ & $1.4 \%$ & $4.6 \%$ & $2.6 \%$ & $1.7 \%$ & $4.1 \%$ \\
1993 & $1.2 \%$ & $0.7 \%$ & $1.7 \%$ & $3.1 \%$ & $1.3 \%$ & $3.1 \%$ \\
1994 & $6.8 \%$ & $1.4 \%$ & $6.5 \%$ & $5.3 \%$ & $1.3 \%$ & $8.8 \%$ \\
\hline Average & $4.9 \%$ & $1.1 \%$ & $5.2 \%$ & $4.4 \%$ & $1.5 \%$ & $5.4 \%$ \\
\hline \hline
\end{tabular}

Table 7: Size distribution of blocks purchased by new shareholders

Size distribution of blocks that are purchased by a new shareholder for the period 1987-1994, separately for non-listed and listed firms. Block size is observed at the direct level of ownership, block ownership is determined at the ultimate level, applying the concept of control. Therefore, purchases by new shareholders refer to changes in ultimate ownership of direct share blocks. Column 1 shows the total number of block purchases by new shareholders. Columns 2, 4, 6, and 8 disaggregate these purchases into four size classes. Columns 3,5,7, and 9 relate the disaggregate number of blocks to the number of all block purchases by new shareholders (column 1). The sample comprises 946 firms (Sample I).

\begin{tabular}{|c|c|c|c|c|c|c|c|c|c|}
\hline & \multirow{3}{*}{$\begin{array}{l}\text { Total number } \\
\text { of purchases }\end{array}$} & \multicolumn{8}{|c|}{ Size of purchased block } \\
\hline & & \multicolumn{2}{|c|}{$[5 \% ; 10 \%[$} & \multicolumn{2}{|c|}{$[10 \% ; 25 \%[$} & \multicolumn{2}{|c|}{$[25 \% ; 50 \%[$} & \multicolumn{2}{|c|}{$[50 \% ; 100 \%]$} \\
\hline & & total & $\%$ & total & $\%$ & total & $\%$ & total & $\%$ \\
\hline Non-listed firms & 178 & 6 & $3.4 \%$ & 24 & $13.5 \%$ & 21 & $11.8 \%$ & 125 & $70.2 \%$ \\
\hline Listed firms & 258 & 11 & $4.3 \%$ & 74 & $28.7 \%$ & 62 & $24.0 \%$ & 107 & $41.5 \%$ \\
\hline
\end{tabular}


Table 8: Causes of control transfers

Characteristics of firms that experience a change in ultimate ownership (control) in year 0 (columns 2 and 4), compared with characteristics of firms that do not experience such a change in any year (columns 1 and 3), separately for non-listed and listed firms. Firms are compared at the mean of each firm characteristic. For firms with a change in control, statistics are calculated for the two years preceding the change (year -1 and year -2) and the year of change (year 0 ). For other firms, statistics refer to the whole period of observation. Firm characteristics include measures of ownership structure (size of largest share block, level in ownership pyramid where control is located, fraction of insider ownership), capital structure (debt-to-assets ratio), and firm size (total sales). The test statistics are heteroscedastic $t$-tests of equal means. ${ }^{*},{ }^{* *}, * * *$ indicates significance at the 0.10, 0.05, and 0.01 levels, respectively. The sample comprises 664 firms (Sample II).

\begin{tabular}{|c|c|c|c|c|c|}
\hline & & \multicolumn{2}{|c|}{ Non-listed firms } & \multicolumn{2}{|c|}{ Listed firms } \\
\hline & & $\begin{array}{l}\text { No change } \\
\text { in control }\end{array}$ & $\begin{array}{c}\text { Change in } \\
\text { control }\end{array}$ & $\begin{array}{l}\text { No change } \\
\text { in control }\end{array}$ & $\begin{array}{c}\text { Change in } \\
\text { control }\end{array}$ \\
\hline \multirow[t]{3}{*}{ Largest block } & year -2 & & $69.4 \% * * *$ & & $50.2 \% * * *$ \\
\hline & year -1 & & $70.8 \% * * *$ & & $50.7 \% * * *$ \\
\hline & year 0 & $87.5 \%$ & $76.5 \% * * *$ & $62.7 \%$ & $55.1 \% * * *$ \\
\hline \multirow[t]{3}{*}{ Debt-to-assets ratio } & year -2 & & $40.9 \% *$ & & $44.5 \% * * *$ \\
\hline & year -1 & & $41.9 \% * *$ & & $46.0 \% * * *$ \\
\hline & year 0 & $36.9 \%$ & $41.9 \% * *$ & $39.9 \%$ & $45.1 \% * * *$ \\
\hline \multirow[t]{3}{*}{ Level of control } & year -2 & & $1.6^{* * *}$ & & 1.4 \\
\hline & year -1 & & $1.7^{*}$ & & 1.4 \\
\hline & year 0 & 1.9 & 2.0 & 1.4 & $1.7^{* * *}$ \\
\hline \multirow[t]{3}{*}{ Sales (in mio. DM) } & year -2 & & $1,541.7^{* *}$ & & $1,975.4^{* * *}$ \\
\hline & year -1 & & $1,592.5^{* *}$ & & $2,042.7^{* * *}$ \\
\hline & year 0 & $2,404.1$ & $1,557.6^{* *}$ & $4,030.3$ & $2,245.0^{* * *}$ \\
\hline \multirow[t]{3}{*}{ Insider ownership } & year -2 & & $12.6 \%$ & & $14.6 \% * * *$ \\
\hline & year -1 & & $10.3 \%$ & & $12.2 \% * * *$ \\
\hline & year 0 & $13.5 \%$ & $5.4 \% * * *$ & $27.3 \%$ & $9.7 \% * * *$ \\
\hline Number of observations & & 1,391 & 621 & 1,443 & 978 \\
\hline
\end{tabular}


Table 9: Industry-adjusted performance as cause of control transfers

Mean industry-adjusted performance of firms that experience a change in ultimate ownership (control) in year 0 (columns 2 and 4), compared with performance of firms that do not experience such a change in any year (columns 1 and 3), separately for non-listed and listed firms. For firms with a change in control, statistics are calculated for the two years preceding the change (year -1 and year -2) and the year of change (year 0). For other firms, statistics refer to the whole period of observation. Performance measures include return on assets (ROA), return on equity (ROE), change in ROA, change in ROE, the fraction of firms reporting an earnings loss, and annual stock market return. All performance measures except the loss indicator are corrected for median performance at the two-digit industry level. The test statistics are heteroscedastic $t$-tests of equal means. ${ }^{*}, * *, * *$ indicates significance at the $0.10,0.05$, and 0.01 levels, respectively. The sample comprises 664 firms (Sample II).

\begin{tabular}{|c|c|c|c|c|c|}
\hline & & \multicolumn{2}{|c|}{ Non-listed firms } & \multicolumn{2}{|c|}{ Listed firms } \\
\hline & & $\begin{array}{l}\text { No change } \\
\text { in control }\end{array}$ & $\begin{array}{c}\text { Change in } \\
\text { control }\end{array}$ & $\begin{array}{l}\text { No change } \\
\text { in control }\end{array}$ & $\begin{array}{c}\text { Change in } \\
\text { control }\end{array}$ \\
\hline \multirow[t]{3}{*}{ Return on assets (ROA) } & year -2 & & $1.3 \%$ & & $1.3 \%$ \\
\hline & year -1 & & $0.3 \%$ & & $0.8 \%$ \\
\hline & year 0 & $0.9 \%$ & $-1.0 \%$ & $1.8 \%$ & $0.9 \%$ \\
\hline \multirow[t]{3}{*}{ Return on equity (ROE) } & year -2 & & $1.7 \%$ & & $2.8 \%$ \\
\hline & year -1 & & $-0.3 \%$ & & $2.7 \%$ \\
\hline & year 0 & $1.4 \%$ & $-4.6 \% * *$ & $2.1 \%$ & $0.1 \%$ \\
\hline \multirow[t]{3}{*}{ Change in ROA } & year -2 & & $-0.7 \%$ & & $-1.8 \% *$ \\
\hline & year -1 & & $-1.4 \%$ & & $-0.4 \%$ \\
\hline & year 0 & $-0.1 \%$ & $-2.2 \% *$ & $-0.4 \%$ & $0.0 \%$ \\
\hline \multirow[t]{3}{*}{ Change in ROE } & year -2 & & $-0.3 \%$ & & $-3.4 \%$ \\
\hline & year -1 & & $-2.3 \%$ & & $-0.9 \%$ \\
\hline & year 0 & $-0.2 \%$ & $-5.8 \% * *$ & $-0.6 \%$ & $-3.0 \%$ \\
\hline \multirow[t]{3}{*}{ Earnings loss } & year -2 & & $6.2 \% * *$ & & $9.9 \%$ \\
\hline & year -1 & & $12.4 \%$ & & $13.7 \% * *$ \\
\hline & year 0 & $13.8 \%$ & $15.5 \%$ & $8.0 \%$ & $11.8 \% *$ \\
\hline \multirow[t]{3}{*}{ Stock market return } & year -2 & & & & $0.1 \%$ \\
\hline & year -1 & & & & $13.3 \% * * *$ \\
\hline & year 0 & & & $1.8 \%$ & $7.1 \%$ \\
\hline Number of observations & & 1,391 & 621 & 1,443 & 978 \\
\hline
\end{tabular}


Table 10: Governance changes and corporate restructuring following control transfers

Characteristics of firms that experience a change in ultimate ownership (control) in year 0 (columns 2 and 4), compared with characteristics of firms that do not experience such a change in any year (columns 1 and 3), separately for non-listed and listed firms. Firms are compared at the mean of each firm characteristic. For firms with a change in control, statistics are calculated for the year preceding the change (year -1), the year of change (year 0), and the two years following the change (year 1 and year 2). For other firms, statistics refer to the whole period of observation. Firm characteristics include measures of governance changes (turnover rates of the CEO and executive directors), asset divestitures (sales rates of fixed and financial assets), layoffs (growth rate of employment), and cost cutting (growth rate of labor costs). The test statistics are heteroscedastic $t$-tests of equal means. ${ }^{*},{ }^{* *},{ }^{* * *}$ indicates significance at the $0.10,0.05$, and 0.01 levels, respectively. The sample comprises 664 firms (Sample II).

\begin{tabular}{|c|c|c|c|c|c|}
\hline & & \multicolumn{2}{|c|}{ Non-listed firms } & \multicolumn{2}{|c|}{ Listed firms } \\
\hline & & $\begin{array}{l}\text { No change } \\
\text { in control }\end{array}$ & $\begin{array}{c}\text { Change in } \\
\text { control }\end{array}$ & $\begin{array}{l}\text { No change } \\
\text { in control }\end{array}$ & $\begin{array}{c}\text { Change in } \\
\text { control }\end{array}$ \\
\hline Turnover of CEO & $\begin{array}{l}\text { year }-1 \\
\text { year } 0 \\
\text { year } 1 \\
\text { year } 2\end{array}$ & $14.2 \%$ & $\begin{array}{l}12.8 \% \\
17.9 \% \\
25.6 \% \text { ** } \\
20.5 \%\end{array}$ & $14.0 \%$ & $\begin{array}{l}10.2 \% \\
21.1 \%{ }^{* *} \\
19.5 \%^{*} \\
21.1 \%^{* *}\end{array}$ \\
\hline $\begin{array}{l}\text { Turnover of executive } \\
\text { directors }\end{array}$ & $\begin{array}{l}\text { year }-1 \\
\text { year } 0 \\
\text { year } 1 \\
\text { year } 2\end{array}$ & $11.5 \%$ & $\begin{array}{l}11.2 \% \\
20.6 \% \text { *** } \\
23.4 \%^{* * *} \\
16.2 \%\end{array}$ & $11.9 \%$ & $\begin{array}{l}10.9 \% \\
19.6 \%^{* * *} \\
15.8 \%^{*} \\
16.5 \%^{* *}\end{array}$ \\
\hline Sales of fixed assets & $\begin{array}{l}\text { year }-1 \\
\text { year } 0 \\
\text { year } 1 \\
\text { year } 2\end{array}$ & $6.6 \%$ & $\begin{array}{l}6.0 \% \\
5.2 \% * \\
8.5 \% \\
5.8 \%\end{array}$ & $6.2 \%$ & $\begin{array}{l}6.9 \% \\
8.8 \% * * \\
7.4 \% \\
7.3 \%\end{array}$ \\
\hline Sales of financial assets & $\begin{array}{l}\text { year }-1 \\
\text { year } 0 \\
\text { year } 1 \\
\text { year } 2\end{array}$ & $14.8 \%$ & $\begin{array}{l}12.1 \% \\
16.7 \% \\
13.8 \% \\
17.7 \%\end{array}$ & $16.2 \%$ & $\begin{array}{l}16.5 \% \\
20.0 \% \\
18.6 \% \\
17.4 \%\end{array}$ \\
\hline Growth rate of employment & $\begin{array}{l}\text { year }-1 \\
\text { year } 0 \\
\text { year } 1 \\
\text { year } 2\end{array}$ & $-1.3 \%$ & $\begin{array}{r}-0.1 \% \\
-3.2 \% \\
1.1 \% \\
-3.2 \%\end{array}$ & $4.6 \%$ & $\begin{array}{l}4.6 \% \\
5.5 \% \\
1.1 \% \\
-2.0 \% * * *\end{array}$ \\
\hline Growth rate of labor costs & $\begin{array}{l}\text { year }-1 \\
\text { year } 0 \\
\text { year } 1 \\
\text { year } 2\end{array}$ & $6.4 \%$ & $\begin{array}{c}3.3 \%^{* *} \\
4.9 \% \\
13.6 \% * * \\
6.8 \%\end{array}$ & $4.6 \%$ & $\begin{array}{c}4.6 \% \\
4.3 \% \\
10.9 \%{ }^{* *} \\
4.3 \%\end{array}$ \\
\hline Number of observations & & 1,391 & 621 & 1,443 & 978 \\
\hline
\end{tabular}


Table 11: Industry-adjusted performance following poor performance

Mean industry-adjusted performance of firms that perform poorly in year -1 and that experience a change in ultimate ownership (control) in year 0 , but not in years $-1,1$, and 2 , relative to zero (columns 1 and 2). Mean industry-adjusted performance of firms that perform poorly in year -1 and that experience a change in control in year 0 , but not in years $-1,1$, and 2 , relative to mean industry-adjusted performance of firms that perform poorly in year -1 and do not experience such a change in any year (columns 3 and 4). Poor performance is defined as negative industryadjusted performance. The statistics are calculated separately for non-listed and listed firms. Performance measures include return on assets (ROA), return on equity (ROE), change in ROA, change in ROE, and annual stock market return. All performance measures are corrected for median performance at the two-digit industry level. The test statistics are $t$-tests of being equal to zero (columns 1 and 2) and heteroscedastic $t$-tests of equal means (columns 3 and 4 ). *, **, *** indicates significance at the $0.10,0.05$, and 0.01 levels, respectively. The sample comprises 55 firms from Sample II for which the above conditions hold.

\begin{tabular}{|c|c|c|c|c|c|}
\hline \multirow[t]{2}{*}{ Performance measure } & & \multicolumn{2}{|c|}{ Relative to zero } & \multicolumn{2}{|c|}{$\begin{array}{c}\text { Relative to performance of } \\
\text { firms without a change } \\
\text { in control }\end{array}$} \\
\hline & & $\begin{array}{l}\text { Non-listed } \\
\text { firms }\end{array}$ & $\begin{array}{l}\text { Listed } \\
\text { firms }\end{array}$ & $\begin{array}{l}\text { Non-listed } \\
\text { firms }\end{array}$ & $\begin{array}{l}\text { Listed } \\
\text { firms }\end{array}$ \\
\hline Return on assets (ROA) & $\begin{array}{l}\text { year }-1 \\
\text { year } 0 \\
\text { year } 1 \\
\text { year } 2\end{array}$ & $\begin{array}{l}-5.0 \% * * * \\
-4.9 \% * * * \\
-2.3 \% * \\
-2.3 \% *\end{array}$ & $\begin{array}{l}-4.8 \% * * * \\
-3.4 \% \\
-2.7 \% * * * \\
0.4 \%\end{array}$ & $\begin{array}{r}0.9 \% \\
-0.7 \% \\
1.4 \% \\
0.7 \%\end{array}$ & $\begin{array}{r}0.0 \% \\
-0.7 \% \\
-0.4 \% \\
2.6 \%\end{array}$ \\
\hline Return on equity (ROE) & $\begin{array}{l}\text { year }-1 \\
\text { year } 0 \\
\text { year } 1 \\
\text { year } 2\end{array}$ & $\begin{array}{l}-10.6 \% * * * \\
-11.3 \% * * * \\
-4.0 \% * \\
-2.3 \%\end{array}$ & $\begin{array}{l}-10.6 \% * * * \\
-10.2 \% * * \\
-6.9 \% * \\
-3.1 \%\end{array}$ & $\begin{array}{r}0.2 \% \\
-3.0 \% \\
2.7 \% \\
3.7 \%\end{array}$ & $\begin{array}{r}-1.3 \% \\
-4.3 \% \\
-1.6 \% \\
2.5 \%\end{array}$ \\
\hline Change in ROA & $\begin{array}{l}\text { year }-1 \\
\text { year } 0 \\
\text { year } 1 \\
\text { year } 2\end{array}$ & $\begin{array}{l}-5.3 \%^{* * *} \\
-0.6 \% \\
3.3 \% * \\
0.0 \%\end{array}$ & $\begin{array}{l}-4.3 \% \text { *** } \\
1.2 \% \\
-0.3 \% \\
1.1 \%\end{array}$ & $\begin{array}{l}-0.6 \% \\
-1.1 \% \\
3.8 \% * * \\
-0.5 \%\end{array}$ & $\begin{array}{r}-0.1 \% \\
1.3 \% \\
-0.4 \% \\
1.1 \%\end{array}$ \\
\hline Change in ROE & $\begin{array}{l}\text { year }-1 \\
\text { year } 0 \\
\text { year } 1 \\
\text { year } 2\end{array}$ & $\begin{array}{l}-9.1 \%^{* * *} \\
-0.8 \% \\
6.3 \% \\
1.4 \%\end{array}$ & $\begin{array}{l}-8.9 \% * * * \\
-1.2 \% \\
3.3 \% \\
3.5 \%\end{array}$ & $\begin{array}{r}0.6 \% \\
-1.7 \% \\
6.4 \% \\
0.2 \%\end{array}$ & $\begin{array}{r}-0.8 \% \\
-1.3 \% \\
2.4 \% \\
3.8 \%\end{array}$ \\
\hline Stock market return & $\begin{array}{l}\text { year }-1 \\
\text { year } 0 \\
\text { year } 1 \\
\text { year } 2\end{array}$ & & $\begin{array}{l}-22.7 \% * * * \\
-1.5 \% \\
-7.0 \% \\
0.5 \%\end{array}$ & & $\begin{array}{r}1.8 \% \\
-4.6 \% \\
-15.4 \% \\
1.6 \%\end{array}$ \\
\hline Number of observations & & 104 & 116 & 104 & 116 \\
\hline
\end{tabular}


Table 12: Hypotheses and empirical results

Summary of hypotheses put forward in Section 2 and empirical results obtained in Section 5.

\begin{tabular}{|c|c|c|c|}
\hline & & Non-listed firms & Listed firms \\
\hline \multicolumn{4}{|c|}{ Changes in ultimate ownership are... } \\
\hline Hypothesis 1 & $\begin{array}{l}\text {...less likely for firms with high } \\
\text { concentration of ownership. }\end{array}$ & supported & supported \\
\hline Hypothesis 2 & $\begin{array}{l}\text {...more likely for firms with high } \\
\text { leverage. }\end{array}$ & supported & supported \\
\hline Hypothesis 3 & $\begin{array}{l}\text {...less likely for firms with complex } \\
\text { ownership structures. }\end{array}$ & supported & rejected \\
\hline Hypothesis 4 & ...less likely for large firms. & supported & supported \\
\hline Hypothesis 5 & $\begin{array}{l}\text {...less likely for firms with high } \\
\text { insider ownership. }\end{array}$ & rejected & supported \\
\hline Hypothesis 6 & $\begin{array}{l}\text {...more likely for firms with poor } \\
\text { performance. }\end{array}$ & rejected & partly supported \\
\hline \multicolumn{4}{|c|}{ Changes in ultimate ownership are followed by... } \\
\hline Hypothesis 7 & ...increased management turnover. & supported & supported \\
\hline Hypothesis 8 & $\begin{array}{l}\text {...increased asset divestitures. } \\
\text {...increased employee layoffs. } \\
\text {...increased cost cutting. }\end{array}$ & $\begin{array}{l}\text { rejected } \\
\text { rejected } \\
\text { rejected }\end{array}$ & $\begin{array}{r}\text { supported } \\
\text { supported } \\
\text { rejected }\end{array}$ \\
\hline Hypothesis 9 & ...improvements in performance. & rejected & rejected \\
\hline
\end{tabular}

Table 13: Data selection procedure

\begin{tabular}{lrr}
\hline \hline Selection criterion & Firms & Firm years \\
\hline Consolidated balance sheet data for the years 1986-1994 & 5,222 & 22,732 \\
Mining, manufacturing, construction, and trade & 3,470 & 15,148 \\
Ownership data & 1,485 & 6,367 \\
No missing values & 1,455 & 6,205 \\
\hline Sample I (at least two continuous years of data) & 946 & 4,882 \\
Sample II (at least four continuous years of data) & 664 & 4,433 \\
\hline \hline
\end{tabular}


Performance:

Return on assets (ROA) Earnings before interest, taxes, and depreciation (EBITDA)/total assets Return on equity (ROE) EBITDA/total equity

Change in ROA

$\triangle R O A_{t}=R O A_{t}-R O A_{t-1}$

Change in ROE

$\triangle R O E_{t}=R O E_{t}-R O E_{t-1}$

Earnings loss

$E B I T D A<0$

Stock market return

Continuous yearly return $R_{t}^{c}=\sum_{w=1}^{n} \frac{R_{w}^{c}}{n} * 52$ with continuous weekly return $R_{w}^{c}=\ln \left(\frac{K_{w}^{p}}{K_{w-1}^{p}}\right)$ with $K_{w}^{p}$ performance value on

Wednesday of week w. $K_{w}^{p}$ is corrected for capital changes, changes of stock's face value, stock splits, and dividend payments.

Ownership structure:

Largest block

Insider ownership

Level of control

Cross ownership
Size of largest share block

Fraction of shares owned by executive and non-exec. directors Level of the end of a control chain in pyramids. For example, Level $=1$ means that control resides with direct shareholder. Cross $=1$ if ultimate owner is part of the web of firms identified by Wenger and Kaserer (1998) and if ultimate owner indirectly owns share block in itself; 0 otherwise

Capital structure:

Debt-to-assets ratio

Total debt to total assets

Interest coverage EBITDA/interest payments

Borrowing ratio Interest payments/EBITDA

Board structure:

Turnover of CEO

Turnover of executive

$C E O_{t}=1$ if chairman of managerial board (Vorstand) changes from year t- 1 to t, 0 otherwise

$\frac{J_{t}+L_{t}}{E_{t}+E_{t-1}}$ with $J_{t}\left(L_{t}\right)$ number of joining (leaving) directors executive directors and $E_{t}$ number of executive directors

Restructuring:

Sales of assets $s_{j t}=\frac{S_{j t}}{T_{j t}}$ with $S_{j t}$ sales of asset class $\mathrm{j}$ in year $\mathrm{t}$ and $T_{j t}$ stock of asset class $\mathrm{j}$ at the beginning of year $\mathrm{t}$

Growth rate of employment

Growth rate of $n_{t}=\frac{N_{t}-N_{t-1}}{N_{t-1}}$ with $N_{t}$ total number of employees in year $\mathrm{t}$ $c_{t}=\frac{C_{t}-C_{t-1}}{C_{t-1}}$ with $C_{t}$ total labor expenditures in year $\mathrm{t}$ labor costs 


\section{Figure 1: Ownership structure of Dornier $\mathrm{GmbH}$ in 1992}

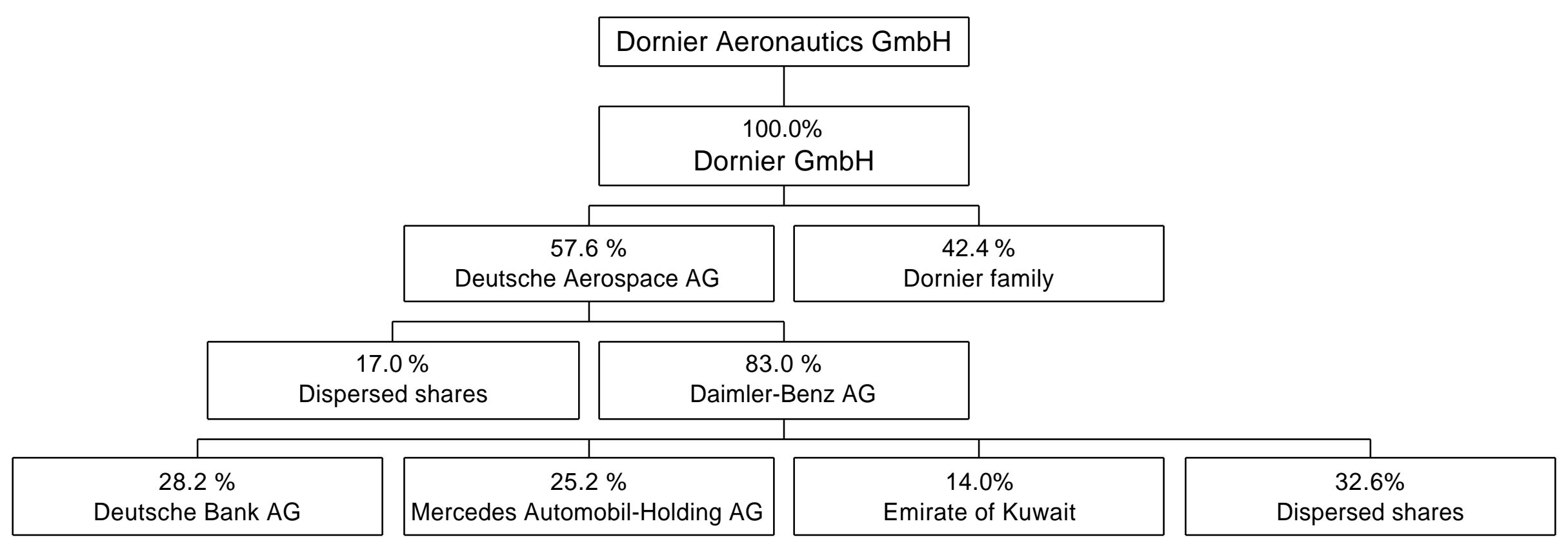




\section{Figure 2: Ownership structure of Boge AG in 1990, 1991 and 1992}

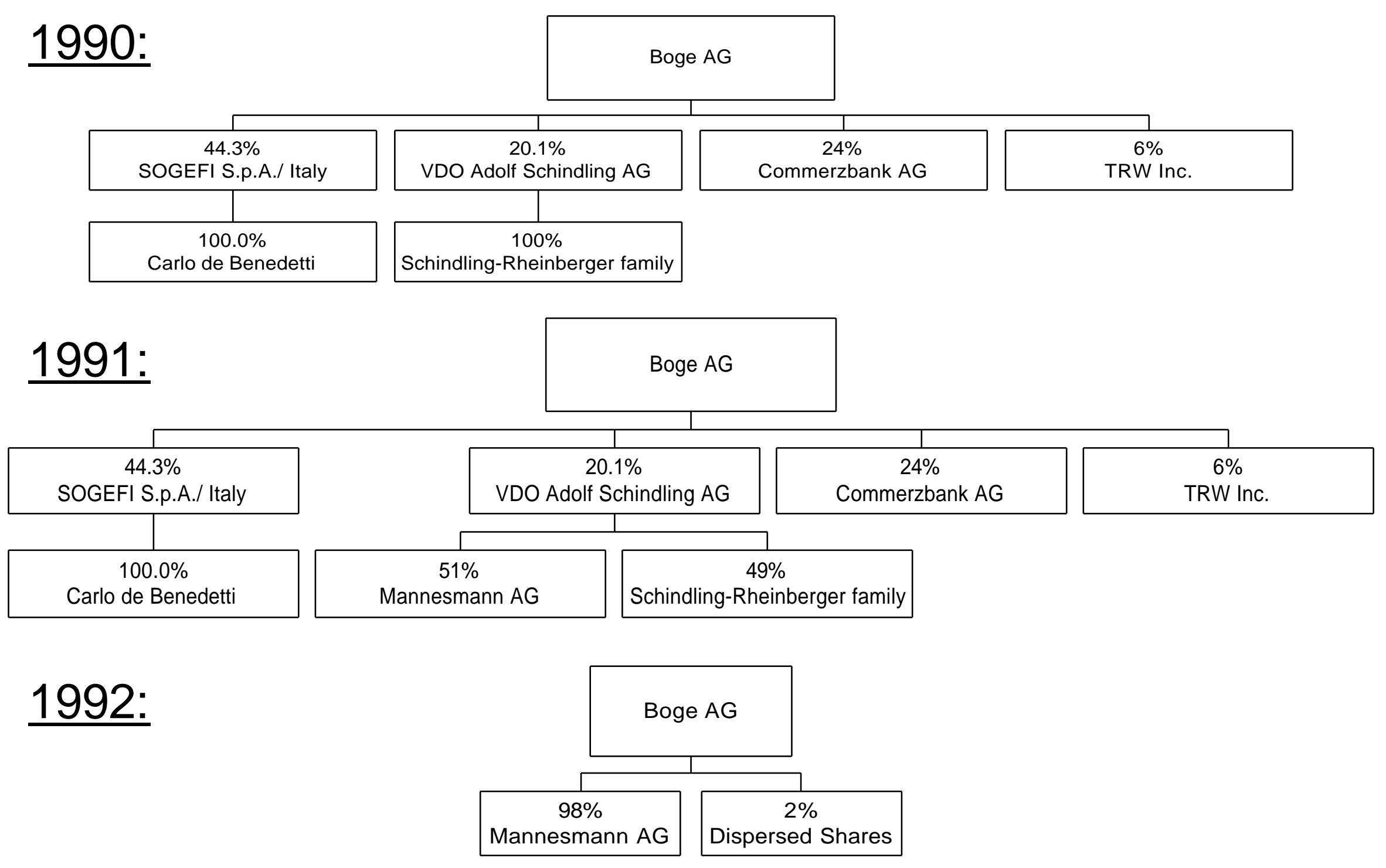

